\title{
Identification of copy number alterations in colon cancer from analysis of amplicon-based next generation sequencing data
}

\author{
Duarte Mendes Oliveira ${ }^{1, *}$, Gianluca Santamaria ${ }^{1, *}$, Carmelo Laudanna $^{1}$, Simona \\ Migliozzi ${ }^{1}$, Pietro Zoppoli ${ }^{1}$, Michael Quist ${ }^{4}$, Catie Grasso ${ }^{5}$, Chiara Mignogna ${ }^{2}$, \\ Laura Elia ${ }^{3}$, Maria Concetta Faniello ${ }^{1}$, Cinzia Marinaro ${ }^{1}$, Rosario Sacco ${ }^{3}$, Francesco \\ Corcione $^{6}$, Giuseppe Viglietto ${ }^{1}$, Donatella Malanga ${ }^{1}$ and Antonia Rizzuto ${ }^{3}$ \\ ${ }^{1}$ Dipartimento di Medicina Sperimentale e Clinica, Università Magna Graecia, Catanzaro, Italy \\ ${ }^{2}$ Dipartimento di Scienze della Salute, Università Magna Graecia, Catanzaro, Italy \\ ${ }^{3}$ Dipartimento di Scienze Mediche e Chirurgiche, Università Magna Graecia, Catanzaro, Italy \\ ${ }^{4}$ Fred Hutchinson Cancer Research Center, Seattle, WA, USA \\ ${ }^{5}$ University of California Los Angeles (UCLA), Los Angeles, CA, USA \\ ${ }^{6}$ UOC Chirurgia Generale, Azienda Ospedaliera dei Colli, Napoli, Italy \\ *These authors contributed equally to this work \\ Correspondence to: Giuseppe Viglietto, email: viglietto@unicz.it \\ Donatella Malanga, email: malanga@unicz.it \\ Keywords: colon cancer; Next generation sequencing; copy number alteration \\ Received: April 04, $2017 \quad$ Accepted: February 28, $2018 \quad$ Published: April 17, 2018 \\ Copyright: Oliveira et al. This is an open-access article distributed under the terms of the Creative Commons Attribution License \\ 3.0 (CC BY 3.0), which permits unrestricted use, distribution, and reproduction in any medium, provided the original author and \\ source are credited.
}

\section{ABSTRACT}

The objective of this study was to determine the feasibility to detect copy number alterations in colon cancer samples using Next Generation Sequencing data and to elucidate the association between copy number alterations in specific genes and the development of cancer in different colon segments. We report the successful detection of somatic changes in gene copy number in 37 colon cancer patients by analysis of sequencing data through Amplicon CNA Algorithm. Overall, we have found a total of 748 significant copy number alterations in 230 significant genes, of which 143 showed CN losses and 87 showed CN gains. Validation of results was performed on 20 representative genes by quantitative $\mathrm{qPCR}$ and/or immunostaining. By this analysis, we have identified 4 genes that were subjected to copy number alterations in tumors arising in all colon segments (defined "common genes") and the presence of copy number alterations in $\mathbf{1 4}$ genes that were significantly associated to one specific site (defined "site-associated genes"). Finally, copy number alterations in ASXL1, TSC1 and IL7R turned out to be clinically relevant since the loss of TSC1 and IL7R was associated with advanced stages and/or reduced survival whereas copy number gain of ASXL1 was associated with good prognosis.

\section{INTRODUCTION}

The development of cancer is driven by the acquisition of somatic genetic alterations that include single nucleotide variations (SNVs), gene fusions and copy-number alterations (CNAs). CNAs are somatic changes that cause the gain or loss of DNA fragments [1-3], and represent the most common alterations of cancer cells [4-9]. They contribute to both onset and progression of cancer by inappropriate activation of proto-oncogenes and/or inactivation of tumor suppressor genes [4, 10-15]. Characterization of CNAs in tumors have helped in the identification of relevant oncogenes including ERBB2 and EGFR, as well as tumor suppressors such as pRB and TP53 [16], resulting into better diagnostics and more appropriate therapy [17-19]. 
Recent studies revealed that development of Colon Cancer (CC) involves stepwise accumulation of CNAs [2023]. $\mathrm{CC}$ is the second most commonly diagnosed cancer in females and the third in males, with over 50,000 new cancer patients in Italy every year [24]. CC is a heterogeneous disease that displays a characteristic molecular stepwise progression [25]. Numerous studies have reported on the identification of somatic CNAs in CC [26-37], which, in some cases, have been associated to clinical outcome or metastatic progression [38-42]. However, many of these studies had inherent limitations due to small sample size, low-resolution assays and/or lack of associated clinical annotation, particularly for early-stage CC.

This notwithstanding, previous studies have established that the most frequent CNAs in $\mathrm{CC}$ are $\mathrm{CN}$ gains at chromosomes 7p, 7q, 13q, 20p, 20q, Xp and Xq and $\mathrm{CN}$ losses at chromosomes $8 \mathrm{p}, 17 \mathrm{p}, 18 \mathrm{p}$ and 18q.27 [16]. Notably, colon adenomas apparently have similar levels of CNAs as carcinomas [43, 44] whereas the highest levels of CNAs were detected in metastatic CC [39]. All these studies have led to the identification of multiple oncogenes (EGFR, ERBB2, CCND1, MET, MYC) and/or tumor suppressors (TP53, APC, SMAD4) [45, 46].

Previous studies of CNAs detection in CC were carried out by quantitative PCR, fluorescence in situ hybridization (FISH), whole-genome array comparative genomic hybridization (aCGH) or single-nucleotide polymorphism (SNP) arrays [47-49]. The recent advent of high-throughput sequencing techniques and the subsequent development of ad hoc algorithms have made available CNAs identification [50, 51]. Recently, Grasso and co-workers have developed an algorithm for assessing CNAs from Next Generation Sequencing (NGS) data generated by amplicon-based DNA libraries derived from Formalin Fixed Paraffin-Embedded (FFPE) tumors [52].

In the present study, we applied this algorithm to DNA sequencing data to determine the feasibility to detect CNAs using NGS and elucidate the association between specific CNAs and cancer originating from different anatomical colon segments.

\section{RESULTS}

\section{Identification of CNAs in colon cancer by analysis of amplicon-based NGS data}

In this manuscript we have applied the Amplicon CNA Algorithm, previously described by Grasso and coworkers [52] to identify somatic CNAs from ampliconbased NGS data generated using the Ion AmpliSeq ${ }^{\mathrm{TM}}$ Comprehensive Cancer Panel (CCP), which provides complete whole exon coverage of the 409 most important cancer-associated genes. As described in a parallel manuscript (Oliveira et al., under revision), we have selected 37 patients among those who underwent surgery for CC at the General Surgery Unit of University Magna
Graecia of Catanzaro in the years 2013-2015. The samples were resected from multiple anatomical segments of the colon: ascending colon (7 patients), descending colon (7 patients), hepatic flexure (8 patients), splenic flexure (5 patients), transverse colon (4 patients) and cecum (6 patients) (Supplementary Figure 1). Complete demographic and clinical information of patients are reported in Supplementary Table 1. NGS was performed in 37 tumor samples and 13 matched PBLs (Oliveira et al., under revision). Figure 1 illustrates the pipeline analysis of NGS data implemented in R statistical environment [53]. The input for the Amplicon CNA Algorithm was the Binary Alignment Multifasta (BAM) file. The use of pooled normal samples as reference has been reported to be a valid alternative to the one-by-one match between tumors and the corresponding normal tissues [52]. The algorithm output consisted in a list of all CNAs identified for each sample analyzed. Overall, 1904 CNA calls were identified. Copy Number $(\mathrm{CN})$ gains were defined as alterations showing $\log 2 \mathrm{CN}$ ratio $\geq 0.1$ and $\mathrm{CN}$ losses were defined as alterations showing $\log 2 \mathrm{CN}$ ratio $\leq-0.1$. Benjamini-Hochberg procedure was used to reduce false discovery rate and CNAs were considered significant when the $q$-value was $\leq 0.05$ (Supplementary File 1).

On the basis of these parameters we found a total of 785 significant CNA calls, of which 328 (41.7\%) were $\mathrm{CN}$ gains and 457 (58.2\%) were $\mathrm{CN}$ losses, distributed along 243 different genes. Finally, for the sake of clarity, we considered significant only the alteration calls that showed concordance in $\geq 65 \%$ of the samples. Using this threshold, we found that the majority of genes with CNAs were concordant (230/243). The remaining 13 genes (DICER1, FGFR1, HOOK3, IGF2, IKBKB, MARK1, NFKB1, NF1, PTPRD, SMAD2, SYNE1, TAF1L, TRIP11) presented discordant calls and were not considered in the rest of the manuscript. We will consider only the 230 genes that showed concordant calls. Among the concordant genes, 143 presented $\mathrm{CN}$ losses and 87 presented CN gains (Supplementary Table 2). The Circos plot shown in Figure 2 summarizes all detected CNAs. The median number of genes per tumor showing $\mathrm{CN}$ gains was 12 (range 1-37) whereas the median number of genes per tumor showing $\mathrm{CN}$ losses was 20 (range $1-41)$. CN gains and losses involved genes located on all chromosomes except chromosome 23 . The heatmap in Figure 3 shows all significant CNAs ordered by cytobands (see also Supplementary Table 3), with CN gains (red) and $\mathrm{CN}$ losses (green).

As indicated in Table 1 (columns 1-8), the most frequent $\mathrm{CN}$ gains were observed at chromosomes 7, 20 and 8 . Frequent $\mathrm{CN}$ gains involved MLL3 at chromosome 7q36.1 $(n=16,43.24 \%)$, AKAP9 at chromosome 7q21.2 $(n=15,40.54 \%)$, ASXL1 at chromosome 20q11.21 $(n=14,37.84 \%)$, PLCG1 at chromosome 20q12 $(n=$ $13,35.14 \%)$, and UBR5 at chromosome 8q22.3 $(n=13$, $35.14 \%)$. 


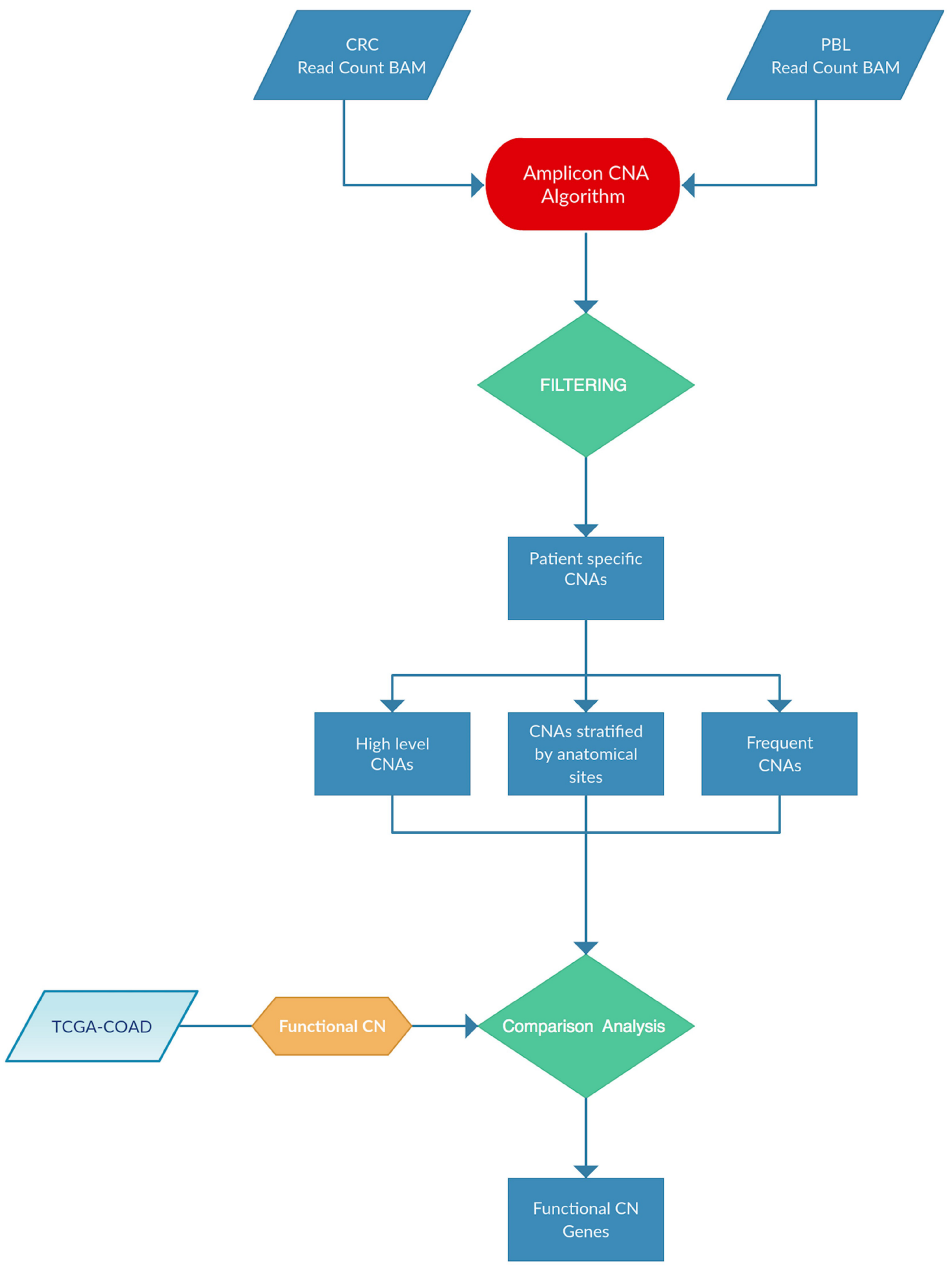

Figure 1:Pipeline analysis implemented for this study. 
Conversely, the most frequent $\mathrm{CN}$ losses were MBD1 at $18 \mathrm{q} 21.1(n=10,27 \%), \mathrm{DCC}$ at $18 \mathrm{q} 21.2(n=$ $13,35.14 \%)$, WHSC $1(n=12,32.43 \%)$ at $4 \mathrm{p} 16.3$, NLRP1 $(n=10,27 \%)$ and RNF213 $(n=9,24.3 \%)$ at $17 \mathrm{p} 13.2$ and $17 \mathrm{q} 25.3$, respectively.

Other genes that, in this study, presented frequent $\mathrm{CN}$ gains were KAT6A at 8p11.21, CSMD3 at 8q23.3, PTPRT at 20q12, DST at $6 \mathrm{p} 12.1$ and ATR at $3 \mathrm{q} 23$. Conversely frequent $\mathrm{CN}$ losses were observed for TGM7 at $15 \mathrm{q} 15.2, \mathrm{EP} 400$ at $12 \mathrm{q} 24.33, \mathrm{CDH} 2$ at $18 \mathrm{q} 12.1, \mathrm{LTK}$ at $15 \mathrm{q} 15.1$ and ERG at 21q22.2.
In Table 2 are listed the genes with the highest values of $\mathrm{CN}$ changes (columns 1-8). Among these, there were CCND1 with a mean $\mathrm{CN}$ ratio of 6.0, CCNE1 with a mean $\mathrm{CN}$ ratio of $4, \mathrm{MAF}$ with a mean $\mathrm{CN}$ ratio of 3.30 , BCL2L1 with a mean CN ratio of 2.19 and CDKN2A with a mean $\mathrm{CN}$ ratio of 0.2 .

Expectedly, most genes showing alterations had already been reported to be associated with the development of colon cancer [22]. However, among the 230 genes that presented significant $\mathrm{CN}$ changes in colon cancer we identified at least 10 whose alterations had not

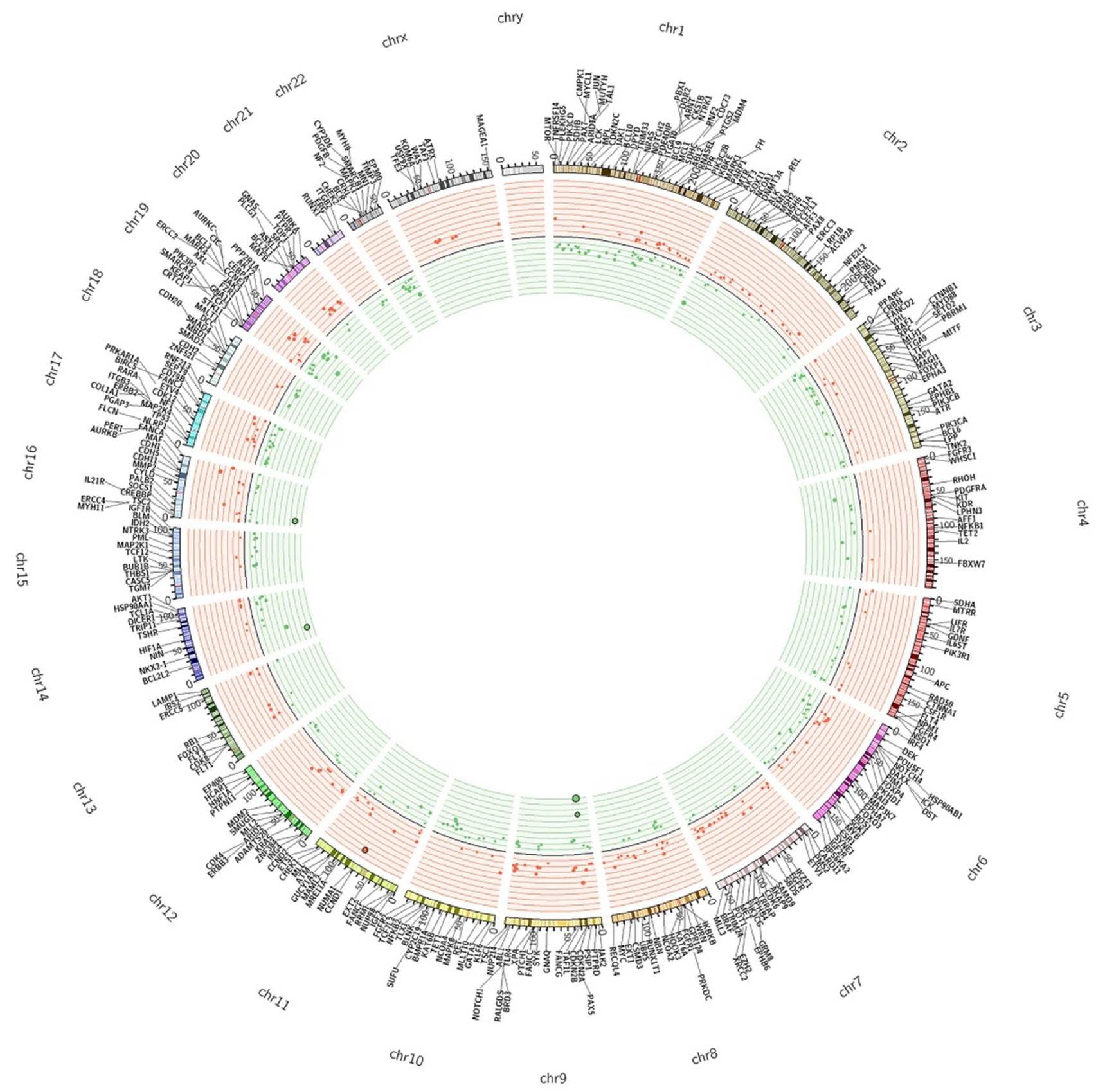

Figure 2: The Circos plot summarizes all CNAs detected in colon cancers samples under analysis. The two outermost tracks report the distributions of 409 genes along the genome; the innermost tracks reported the values of the $\log 2 \mathrm{CN}$ ratio. Genes with altered $\mathrm{CN}$ are distinguished by colour as deletions (green) and amplifications (red). 
been previously associated to colon cancer. Of these 4 genes were subjected to CN gains (DST, KLF6, FANCA, CSMD3) and 6 were subjected to CN losses (TGM7, NKX2-1, RHOH, RNF213, ERG, and CRBN).

\section{Validation of NGS results by Q-PCR analysis and immunohistochemistry analysis}

Subsequently, we used Q-PCR to validate the results obtained through the bioinformatics analysis of NGS data. In Figure 4 we reported representative Q-PCR analysis relative to 2 genes showing $\mathrm{CN}$ gains (MAF and BCL2L1) and 2 genes with CN losses (SMAD4, CDKN2A). In Supplementary Figure 2 we reported representative Q-PCR relative to additional genes showing significant CNVs. Overall Q-PCR results were consistent with bioinformatics analysis of NGS data, also in those genes that resulted discordant (Supplementary Figure 2). Immunostaining analysis demonstrated that the observed CNA in the gene encoding CCND1 resulted into cyclin D1 protein overexpression in CC27 (see Figure 5).
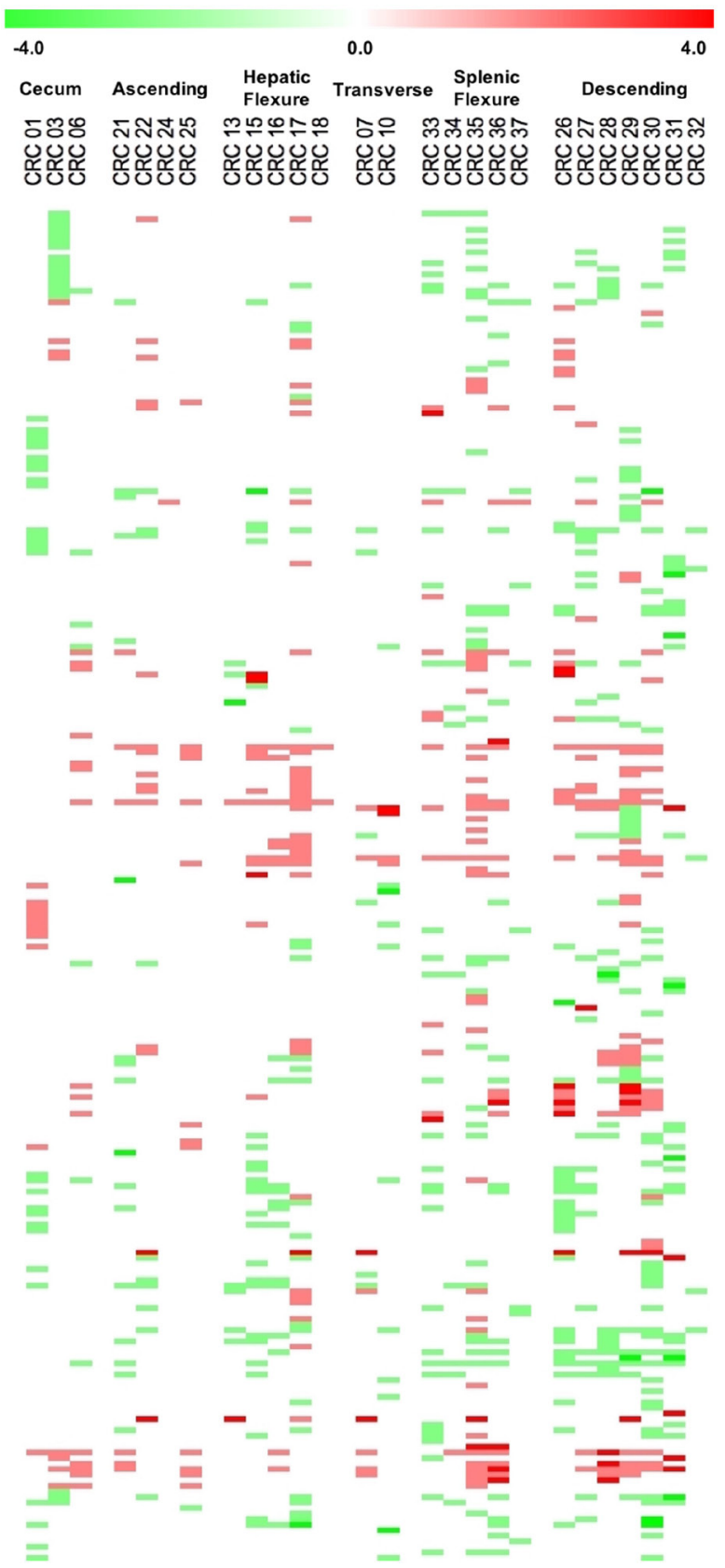

Figure 3: Heatmap representation of the data across all the cytobands harbouring CNAs ordered by chromosome position. Colour intensity is proportional to degree of CNAs, one-copy gains are indicated in light red and one-copy losses are indicated in light green. 
Table 1: Most frequently detected CNAs and corresponding values in TCGA

\begin{tabular}{|c|c|c|c|c|c|c|c|c|c|c|c|}
\hline \multicolumn{8}{|c|}{ CNAS DETECTED IN 37 CC } & \multicolumn{4}{|c|}{ TCGA } \\
\hline $\begin{array}{l}\text { Gene } \\
\text { symbol }\end{array}$ & $\begin{array}{c}\text { Chromosome } \\
\text { band }\end{array}$ & 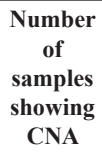 & $\begin{array}{c}\text { Percentage } \\
\text { of samples } \\
\text { showing } \\
\text { CNA }\end{array}$ & $\begin{array}{c}\log 2 \\
\text { (CNA)* }\end{array}$ & $\begin{array}{c}\text { Mean CN } \\
\text { ratio ** }\end{array}$ & $\begin{array}{l}\text { Range of } \\
\text { CN ratio }\end{array}$ & $\begin{array}{l}\text { Type of } \\
\text { CNA }\end{array}$ & $\begin{array}{c}\text { Percentage } \\
\text { of samples } \\
\text { showing CN } \\
\text { GAIN }\end{array}$ & $\begin{array}{c}\text { Number of } \\
\text { samples } \\
\text { showing CN } \\
\text { GAIN }\end{array}$ & $\begin{array}{c}\text { Percentage } \\
\text { of samples } \\
\text { showing CN } \\
\text { LOSS }\end{array}$ & $\begin{array}{c}\text { Number of } \\
\text { samples } \\
\text { showing } \\
\text { CN LOSS }\end{array}$ \\
\hline MLL3 & $7 \mathrm{q} 36.1$ & 16 & 43.24 & 0.41 & 1.34 & $1.14-1.49$ & GAIN & 47.21 & 169 & 1.96 & 7 \\
\hline AKAP9 & $7 \mathrm{q} 21.2$ & 15 & 40.54 & 0.47 & 1.4 & $1.21-1.52$ & GAIN & 47.49 & 170 & 1.12 & 4 \\
\hline ASXL1 & $20 \mathrm{q} 11.21$ & 14 & 37.84 & 0.72 & 1.66 & $1.40-2.10$ & GAIN & 70.95 & 254 & 0 & 0 \\
\hline UBR5 & $8 \mathrm{q} 22.3$ & 13 & 35.14 & 0.54 & 1.47 & $1.23-1.72$ & GAIN & 55.87 & 200 & 1.96 & 7 \\
\hline PLCG1 & $20 \mathrm{q} 12$ & 13 & 35.14 & 0.89 & 1.88 & $1.39-2.55$ & GAIN & 71.23 & 255 & 0.56 & 2 \\
\hline KAT6A & $8 \mathrm{p} 11.21$ & 9 & 24.32 & 0.79 & 1.79 & $1.43-3.22$ & GAIN & 42.74 & 153 & 9.5 & 34 \\
\hline DST & $6 \mathrm{p} 12.1$ & 8 & 21.62 & 0.36 & 1.29 & $1.17-1.42$ & GAIN & 19.27 & 69 & 8.38 & 30 \\
\hline ATR & $3 \mathrm{q} 23$ & 7 & 18.92 & 0.49 & 1.41 & $1.19-1.54$ & GAIN & 14.53 & 52 & 7.82 & 28 \\
\hline BRAF & $7 \mathrm{q} 34$ & 7 & 18.92 & 0.66 & 1.58 & $1.41-1.67$ & GAIN & 47.77 & 171 & 1.12 & 4 \\
\hline CSMD3 & $8 \mathrm{q} 23.3$ & 7 & 18.92 & 0.53 & 1.47 & $1.29-1.92$ & GAIN & 55.87 & 200 & 2.51 & 9 \\
\hline DCC & $18 \mathrm{q} 21.2$ & 13 & 35.14 & -0.61 & 0.66 & $0.54-0.81$ & LOSS & 2.23 & 8 & 61.17 & 219 \\
\hline WHSC1 & $4 \mathrm{p} 16.3$ & 12 & 32.43 & -0.50 & 0.71 & $0.63-0.75$ & LOSS & 2.23 & 8 & 27.65 & 99 \\
\hline NLRP1 & $17 \mathrm{p} 13.2$ & 10 & 27.03 & -0.60 & 0.66 & $0.55-0.76$ & LOSS & 3.63 & 13 & 53.07 & 190 \\
\hline MBD1 & $18 \mathrm{q} 21.1$ & 10 & 27.03 & -0.67 & 0.63 & $0.54-0.72$ & LOSS & 2.79 & 10 & 59.22 & 212 \\
\hline EP400 & $12 \mathrm{q} 24.33$ & 9 & 24.32 & -0.51 & 0.7 & $0.56-0.76$ & LOSS & 18.99 & 68 & 12.01 & 43 \\
\hline TGM7 & $15 \mathrm{q} 15.2$ & 9 & 24.32 & -0.71 & 0.61 & $0.50-0.72$ & LOSS & 2.79 & 10 & 37.43 & 134 \\
\hline RNF213 & $17 \mathrm{q} 25.3$ & 9 & 24.32 & -0.36 & 0.78 & $0.71-0.86$ & LOSS & 23.46 & 84 & 12.01 & 43 \\
\hline ERG & $21 \mathrm{q} 22.2$ & 9 & 24.32 & -0.67 & 0.63 & $0.48-0.78$ & LOSS & 4.75 & 17 & 27.93 & 100 \\
\hline GATA2 & $3 q 21.3$ & 8 & 21.62 & -0.85 & 0.56 & $0.45-0.65$ & LOSS & 13.97 & 50 & 7.54 & 27 \\
\hline LTK & $15 \mathrm{q} 15.1$ & 8 & 21.62 & -0.64 & 0.64 & $0.55-0.72$ & LOSS & 2.79 & 10 & 37.43 & 134 \\
\hline
\end{tabular}

"Base 2 logarithm of CN ratio.

**Ratio of the Tumor Vs Normal intensity signal.

\section{Comparison of the results with Colon Adenocarcinoma dataset present in public repositories}

We validated the results obtained in this study relative to the association of genes with CNAs and localization of tumors in colon segments by analysing the Colon Adenocarcinoma dataset within The Cancer Genome Atlas database (COAD-TCGA). Within this dataset, 358 tumor samples arising from different colon segments were present. Eighty tumors derived from ascending colon, 146 from descending colon, 6 from splenic flexure, 16 from hepatic flexure, 84 from cecum and 27 from transverse colon.

We further validated the analysis of CNAs by investigating the correlation between the 230 genes showing CNAs identified in this study and the corresponding mRNA expression reported in the COADTCGA dataset. The analysis was performed by a linear regression model, which allowed the identification of genes presenting direct association between $\mathrm{CN}$ changes (i.e. amplification/loss) and RNA expression (i.e. overexpression/under-expression). Among the identified 230 genes with significant CNAs, 69 genes (30\%) showed a statistically significant Pearson correlation value higher than $0.45\left(R^{2}>0.2, p\right.$-value $\left.\leq 0.01\right)$. See Supplementary
Table 4 for further details. Notably, some among the 69 genes with a significant correlation between $\mathrm{CN}$ changes and RNA expression are involved in the development of CC, such as SMAD2, ASXL1, PLCG1, UBR5, TOP1 and MBD1. In Figure 6 are reported two of the genes that showed the most significant correlation between CNAs and mRNA expression (ASXL1 and MBD1).

\section{Clinical-pathological correlations}

For clinical analysis we selected those genes that presented concordant CNAs in at least $5 \%$ of the samples. We found that 60 , among 230 significant genes, presented CNAs in $\geq 5 \%$ of patients and correlated them with clinical and pathological parameters such as node status $(\mathrm{N})$, stage, tumor size (T) and/or presence of metastasis (M1) ( $p$-value $\leq 0.05)$. See Supplementary Table 5. Expectedly, Univariate Cox Regression analysis demonstrated that the parameters T, M and stage were predictors of overall survival (OS) (see Table 3).

Subsequently, the genetic status of CC patients $(n=35)$ was correlated with OS and the gain of ASXL1, loss of TSC1 or loss of IL7R predicted poor prognosis, as shown by the corresponding Kaplan-Meier curves (see Figure 7).

In particular, the average 4-year survival rate of all CC patients was $86 \%$. Upon stratification for the status of 
Table 2: Genes showing high level of $\mathrm{CN}$ alteration and corresponding values in TCGA

\begin{tabular}{|c|c|c|c|c|c|c|c|c|c|c|c|}
\hline \multicolumn{8}{|c|}{ CNAS DETECTED IN 37 CC } & \multicolumn{4}{|c|}{ TCGA } \\
\hline $\begin{array}{l}\text { Gene } \\
\text { symbol }\end{array}$ & $\begin{array}{c}\text { Chromosome } \\
\text { band }\end{array}$ & $\begin{array}{c}\text { Number of } \\
\text { samples } \\
\text { showing } \\
\text { CNA }\end{array}$ & $\begin{array}{c}\text { Percentage } \\
\text { of samples } \\
\text { showing CNA }\end{array}$ & $\begin{array}{c}\text { Log2 } \\
\text { (CNA) }\end{array}$ & $\begin{array}{c}\text { Mean } \\
\text { CN } \\
\text { Ratio }^{* *}\end{array}$ & $\begin{array}{l}\text { Range of } \\
\text { CN ratio }\end{array}$ & $\begin{array}{l}\text { Type } \\
\text { of } \\
\text { CNA }\end{array}$ & $\begin{array}{c}\text { Percentage } \\
\text { of samples } \\
\text { showing CN } \\
\text { GAIN }\end{array}$ & $\begin{array}{c}\text { Number of } \\
\text { samples } \\
\text { showing } \\
\text { CN GAIN }\end{array}$ & $\begin{array}{c}\text { Percentage } \\
\text { of samples } \\
\text { showing CN } \\
\text { LOSS }\end{array}$ & $\begin{array}{c}\text { Number of } \\
\text { samples } \\
\text { showing CN } \\
\text { LOSS }\end{array}$ \\
\hline CCND1 & $11 \mathrm{q} 13.3$ & 1 & 2.70 & 2.58 & 6 & $5.99-5.99$ & GAIN & 41 & 11.45 & 51 & 14.25 \\
\hline CCNE1 & $19 \mathrm{q} 12$ & 1 & 2.70 & 2.03 & 4.09 & $4.09-4.09$ & GAIN & 72 & 20.11 & 25 & 6.98 \\
\hline MAF & $16 \mathrm{q} 23.2$ & 6 & 16.21 & 1.52 & 2.92 & $2.48-4.16$ & GAIN & 84 & 23.46 & 23 & 6.42 \\
\hline BCL2L1 & $20 \mathrm{q} 11.21$ & 2 & 5.40 & 1.41 & 2.66 & $2.63-2.68$ & GAIN & 254 & 70.95 & 0 & 0 \\
\hline SRC & $20 \mathrm{q} 11.23$ & 2 & 5.40 & 1.39 & 2.92 & $1.62-4.21$ & GAIN & 255 & 71.23 & 1 & 0.28 \\
\hline IRS2 & $13 q 34$ & 1 & 2.70 & 1.35 & 2.55 & $2.54-2.54$ & GAIN & 211 & 58.94 & 7 & 1.96 \\
\hline CEBPA & $19 \mathrm{q} 13.11$ & 6 & 16.21 & 1.31 & 2.53 & $1.95-3.54$ & GAIN & 69 & 19.27 & 25 & 6.98 \\
\hline PMS2 & $7 \mathrm{p} 22.1$ & 1 & 2.70 & 1.11 & 2.16 & $2.15-2.15$ & GAIN & 195 & 54.47 & 1 & 0.28 \\
\hline FANCA & $16 \mathrm{q} 24.3$ & 1 & 2.70 & 1.11 & 2.15 & $2.15-2.15$ & GAIN & 85 & 23.74 & 27 & 7.54 \\
\hline CDK8 & $13 \mathrm{q} 12.13$ & 3 & 8.10 & 1.09 & 2.18 & $1.57-2.69$ & GAIN & 214 & 59.78 & 8 & 2.23 \\
\hline CDKN2A & $9 \mathrm{p} 21.3$ & 1 & 2.70 & -2.13 & 0.23 & $0.22-0.22$ & LOSS & 60 & 16.76 & 48 & 13.41 \\
\hline NPM1 & $5 \mathrm{q} 35.1$ & 1 & 2.70 & -1.26 & 0.42 & $0.41-0.41$ & LOSS & 24 & 6.7 & 67 & 18.72 \\
\hline TCL1A & $14 q 32.13$ & 1 & 2.70 & -1.24 & 0.42 & $0.42-0.42$ & LOSS & 25 & 6.98 & 118 & 32.96 \\
\hline CHEK2 & $22 \mathrm{q} 12.1$ & 1 & 2.70 & -1.19 & 0.44 & $0.43-0.43$ & LOSS & 9 & 2.51 & 117 & 32.68 \\
\hline PAX5 & $9 \mathrm{p} 13.2$ & 1 & 2.70 & -1.17 & 0.45 & $0.44-0.44$ & LOSS & 59 & 16.48 & 41 & 11.45 \\
\hline SUFU & $10 \mathrm{q} 24.32$ & 1 & 2.70 & -1.07 & 0.48 & $0.47-0.47$ & LOSS & 12 & 3.35 & 80 & 22.35 \\
\hline HSP90AA1 & $14 \mathrm{q} 32.31$ & 1 & 2.70 & -1.03 & 0.49 & $0.48-0.48$ & LOSS & 24 & 6.7 & 118 & 32.96 \\
\hline FOXO3 & $6 \mathrm{q} 21$ & 3 & 8.10 & -1 & 0.5 & $0.47-0.51$ & LOSS & 51 & 14.25 & 49 & 13.69 \\
\hline NRAS & $1 \mathrm{p} 13.2$ & 1 & 2.70 & -0.99 & 0.5 & $0.50-0.50$ & LOSS & 15 & 4.19 & 88 & 24.58 \\
\hline FBXW7 & $4 \mathrm{q} 31.3$ & 2 & 5.40 & -0.94 & 0.52 & $0.49-0.55$ & LOSS & 13 & 3.63 & 101 & 28.21 \\
\hline
\end{tabular}

"Base 2 logarithm of $\mathrm{CN}$ ratio.

"Ratio of the Tumor Vs Normal intensity signal.

ASXL1, TSC1 or IL7R genes, the 4-year survival rates of CNA-negative patients were $73.3 \%$ for ASXL1, 91\% for TSC1 and 91\% for IL7R. Conversely, the 4-year survival rates of patients showing gain of ASXL1, loss of TSC1 and loss of IL7R were $100 \%, 33.3 \%$ and $33.3 \%$, respectively. Patients with CN gain in ASXL1 showed a mean survival time of 48 months with no dead among the 14 patients under analysis. Conversely, ASXL1-negative patients showed mean survival of 41 , with 5 dead patients out of 22 .

Patients with CN loss in TSC1 (2 dead patients out of 3) showed mean survival of 34 months whereas patients with no TSC1 alterations ( 3 dead patients out of 33) showed mean survival of 45 months. Patients with CN loss in IL7R (2 dead patients out of 3 ) showed mean survival time of 34 months in comparison with patients showing normal genetic status of IL7R, mean survival of 45 months (3 dead patients out of 33).

However, none of the covariates that resulted significant in Univariate analysis turned out to be independent prognostic factors by Multivariate Cox Regression analysis.

\section{Genes showing CNAs in colon cancer arising in different anatomical segments}

In order to identify a specific pattern of genetic alterations based on tumor site, we stratified genes with
$\mathrm{CN}$ alterations according to the anatomical localization of the tumor (ascending colon, descending colon, transverse colon, hepatic flexure, splenic flexure and cecum). Genes that presented gains or losses in all colon segments were defined "common genes". Genes that presented gains or losses significantly associated to one anatomic colon segment were defined "site-associated genes". "Common genes" and "site-associated genes" are listed in Supplementary Tables 6 and Table 4, respectively.

Analysis of the results demonstrated that tumors in the ascending colon presented 49 genes with CNAs (26 gains and 23 losses) with a mean value of $14.25 \mathrm{CNAs} /$ tumor (1-24); Tumors arising in the descending colon presented 169 genes with CNAs (53 gains and 108 losses, 8 discordants) with a mean value of $40.85 \mathrm{CNAs} /$ tumor (range 4-61); tumors arising in transverse colon presented 23 genes with CNAs (8 gains and 15 losses) with a mean value of 12.5 CNAs/ tumor (range 10-15); tumors in the hepatic flexure presented 90 genes with CNAs (40 gains and 48 losses, 2 discordant) with a mean value of $24.8 \mathrm{CNAs} /$ tumor (range 2-61); tumors in the splenic flexure presented 111 genes with CNAs (46 gains and 62 losses, 3 discordant) with a mean value of 32.8 CNAs/tumor (range 9-65); and tumors in the cecum presented 75 genes with CNAs (28 gains and 47 losses) with a mean value of 26.6 CNAs/tumor (range 20-36). See circos plots in Supplementary Figures 3-8. 

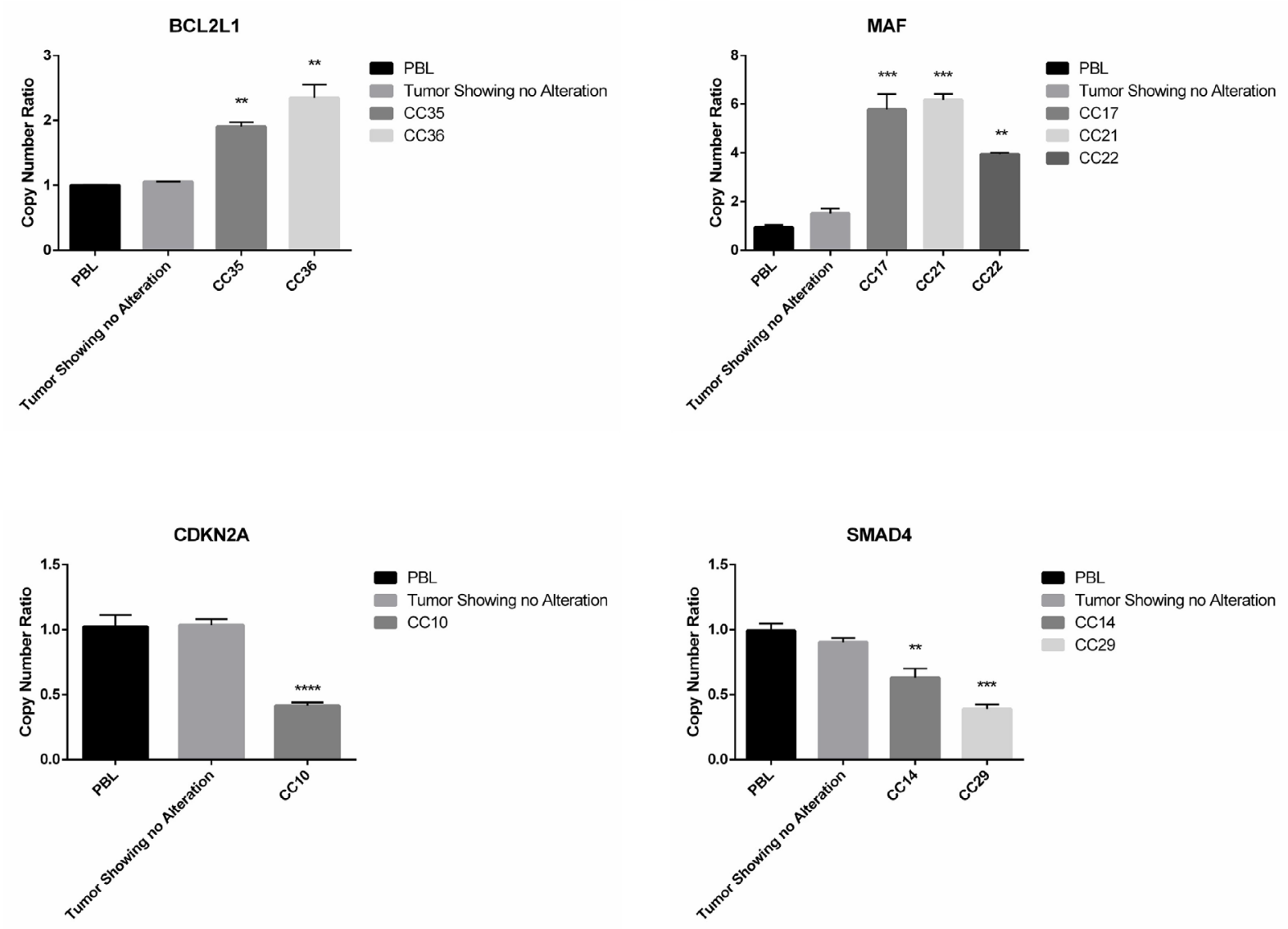

Figure 4: Q-PCR analysis of samples presenting CNAs in SMAD4, CDKN2A, MAF and BCL2L1. Q-RT-PCR analysis of $\mathrm{CN}$ losses in SMAD4 and CDKN2A and of CN gains in MAF and BCL2L1. Values are expressed as CN ratio using as standard the median value of 3 PBL samples set as 1 . Tumors presenting normal $\mathrm{CN}$ for the specific genes were also included in each experiment. Statistical significance as indicated when confronted with PBL.

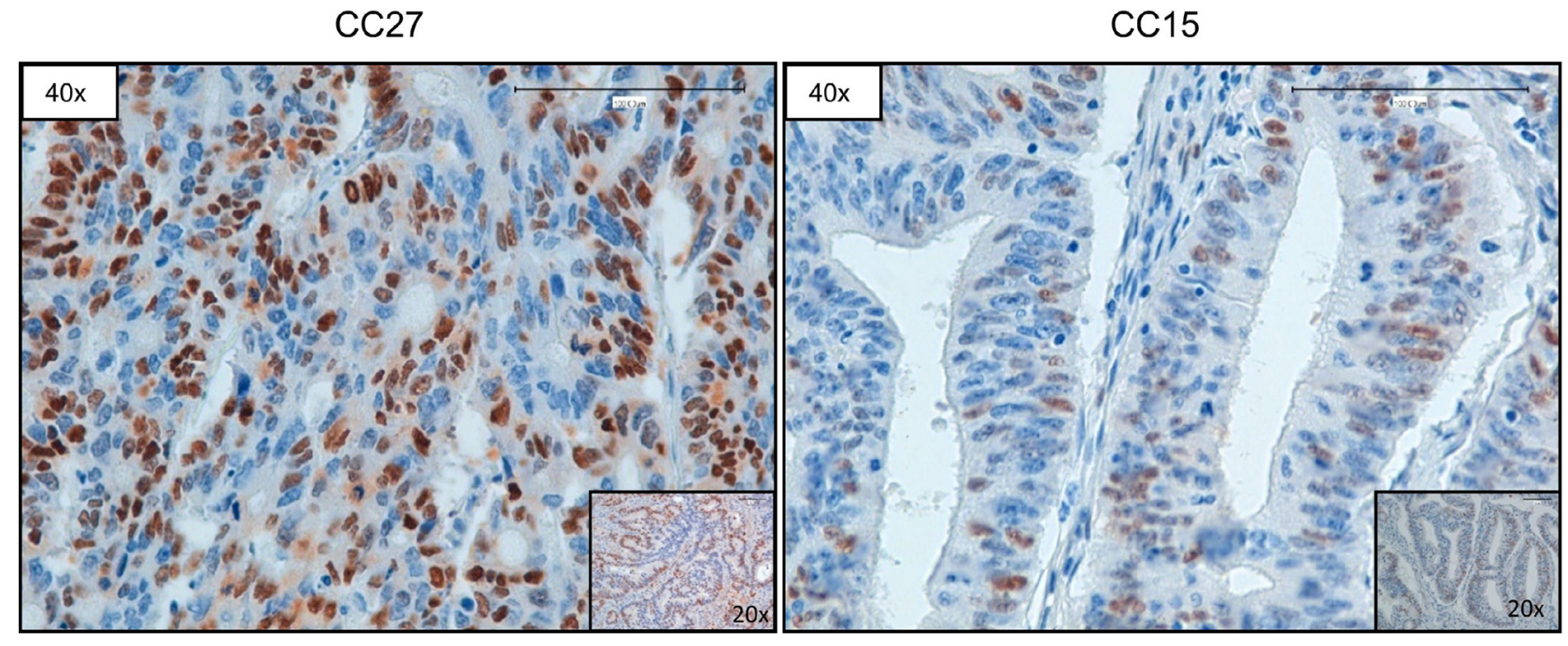

Figure 5: Representative images of CCND1 immunostaining. Sample CC27 (with CN gain of CCND1) and sample CC15 (with normal $\mathrm{CN}$ of CCND1), respectively. Magnification as indicated. 
Among "common genes", CN gains were observed in PLCG1 and ASXL1 genes, whereas CN losses were observed in NLRP1 and WHSC1 genes.

"Site-associated genes" were identified by use of a chisquare test with a threshold of significance set at $p$-value $\leq 0.05$. As listed in Table 4, "site-associated genes" that showed significant association with tumors arising in specific colon sites were 14. Among these, $\mathrm{CN}$ losses were identified in APC, DCC, MBD1, NOTCH2, PDGFB, PKHD1, PIK3R1, RET, RNF213, SMAD4 and WRN whereas CN gains were identified in BCL2L1, RB1 and UBR5.

Among the 14 "site-associated genes" that showed the most significant association with colon segments, PDGFB, SMAD4, RB1, BCL2L1 showed anatomical position dependency for only one site with highly significant $p$-values $(\leq 0.01)$. CN loss of PDGFB was observed only in tumors from splenic flexure, CN loss of SMAD4 was observed only in tumors from descending colon, whereas $\mathrm{CN}$ gain of RB1 was observed only in tumors from descending colon and CN gain of BCL2L1 was observed only in tumors from splenic flexure.

On the other hand, CN loss of WRN, NOTCH2, APC and PIK3R1 were observed in tumors arising in two colon segments. WRN was lost in descending colon tumors $(57 \%)$ and transverse colon tumors (25\%); NOTCH2 was lost in tumors arising in splenic flexure (60\%) and cecum $(17 \%)$; APC was lost in tumors arising in descending colon (43\%) and splenic flexure (40\%); PIK3R1 was lost in tumors of descending colon (43\%) and splenic flexure (40\%).
A

MBD1 Correlation

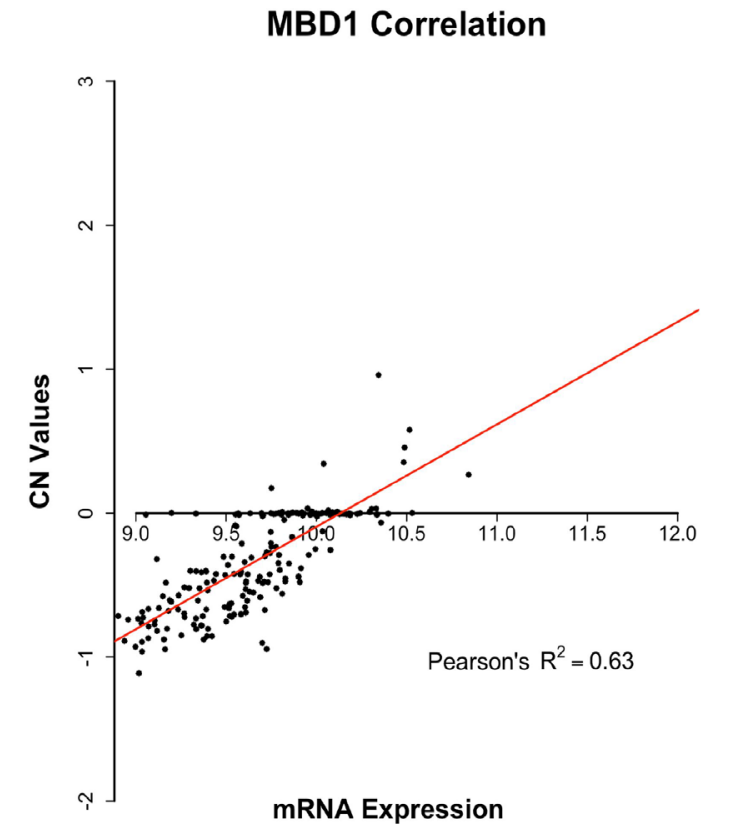

Finally, PKHD1, RET, MDB1 RNF213, DCC and UBR5 showed less specific dependency on anatomical position. PKHD1 and RET were lost predominantly in splenic flexure tumors and descending colon tumors $(60 \%$ and $29 \%$, respectively) and less frequently in hepatic flexure tumors (12.5\%); MDB1 was lost predominantly in tumors from ascending colon and splenic flexure $(85 \%$ and $60 \%$, respectively) and less frequently in hepatic flexure tumors (12.5\%); RNF213 was lost predominantly in descending colon tumors $(71 \%)$ but also in tumors from hepatic flexure, transverse colon and ascending colon $(25 \%, 25 \%, 14 \%)$; DCC was lost in tumors from 5 different segments: splenic flexure, descending colon, ascending colon, cecum and hepatic flexure $(80 \%, 86 \%$, $14 \% 17 \%, 12.5 \%$ ); UBR5 showed CN gain in tumors from splenic flexure, descending colon, transverse colon, and hepatic flexure $(80 \%, 57 \%, 50 \%$ and $37.5 \%$, respectively).

Given the limited number of samples analysed in the cohort of patients under study here, the significance of the anatomical position dependency shown for the 14 "site-associated genes" described above was investigated using a larger dataset of CC (COAD-TCGA). Notably, we found a significant association for 7 of the "site-associated genes" reported in this study also for samples present in COAD-TCGA $(n=358)$. In particular, CNAs in MBD1, SMAD4, PIK3R1, DCC, WRN, RB1 were significantly associated with tumors originating in descending colon whereas CNAs in NOTCH2 was associated with tumors originating in splenic flexure $(p$-value $<0.05)$.
B

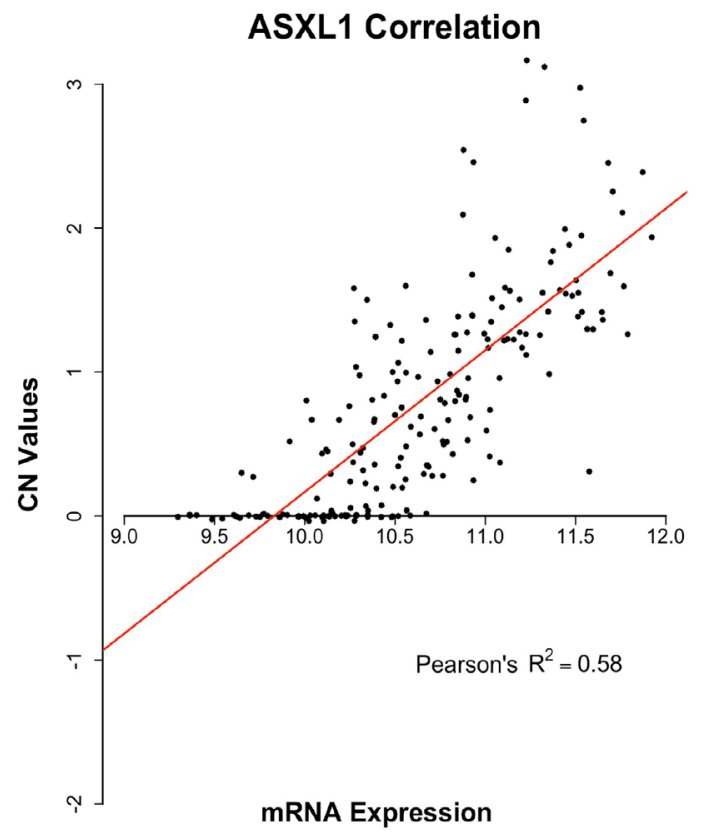

Figure 6: Scatter plots representing Pearson correlation between CN and mRNA expression. Scatter plots showing Pearson correlation between CN and mRNA expression as downloaded from the COAD-TCGA dataset. (A) Pearson correlation between $\mathrm{CN}$ and mRNA expression of MBD1 $\left(R^{2}=0.62\right)$. (B) Pearson correlation between $\mathrm{CN}$ and mRNA expression of ASXL1 $\left(\mathrm{R}^{2}=0.58\right)$. Linear regression lines are represented in red, $\mathrm{CN}$ value $=0$ represent diploid status. 
Table 3: Univariate Cox regression analysis of OS of CC patients, genes showing CNAs and the clinical covariates previously selected by Log-Rank test

\begin{tabular}{lccc}
\hline \multicolumn{1}{c}{ Covariates } & OS & p-value \\
\hline T (TMN) (2-3/4) & HR & $\mathbf{9 5 \%}$ CI & $\mathbf{0 . 0 0 8}^{*}$ \\
Stage (I + II + III/IV) & 11.2 & $1.16-108$ & $\mathbf{0 . 0 0 2 2}^{*}$ \\
M (TNM) stage (M0/M1) & 0.08 & $0.013-0.563$ & $\mathbf{0 . 0 0 2}^{*}$ \\
TSC1 & 11.37 & $1.77-72.8$ & $\mathbf{0 . 0 5}^{*}$ \\
IL7R & 5.8 & $0.85-39.38$ & $\mathbf{0 . 0 5}^{*}$ \\
ASXL1 & 5.8 & $0.85-39.39$ & $\mathbf{0 . 0 4}^{*}$ \\
\hline
\end{tabular}

" $p$-value $\leq 0.05$.

These findings confirmed the significance of the anatomical position dependency shown for at least 7 out of 14 "site-associated genes" reported in this study, indicating that tumors arising in different colon segments may be caused by alterations that occur in different genes.

A

TSC1

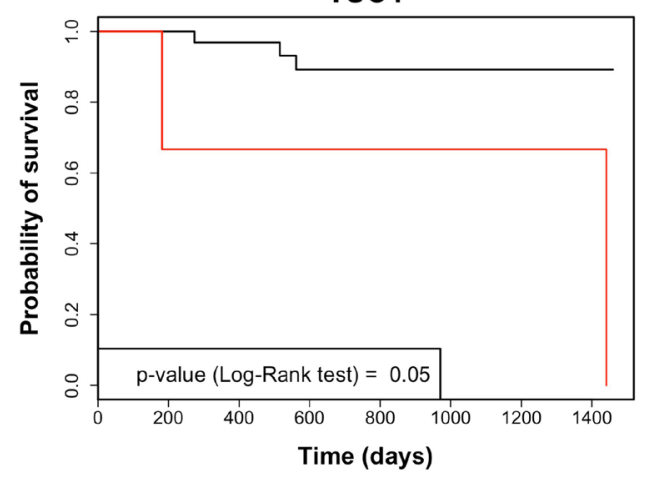

DEL

C

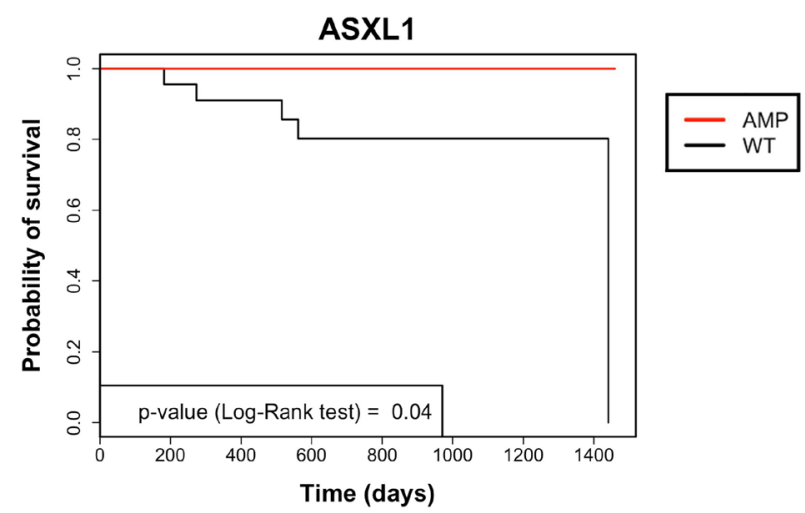

\section{DISCUSSION}

In this manuscript, we have applied a previously described Amplicon CNA Algorithm, to investigate the presence of somatic CNAs in tumors originating in different colon sites [52]. This analysis was performed on NGS data generated using the Ion AmpliSeq ${ }^{\mathrm{TM}} \mathrm{CCP}$, which

B

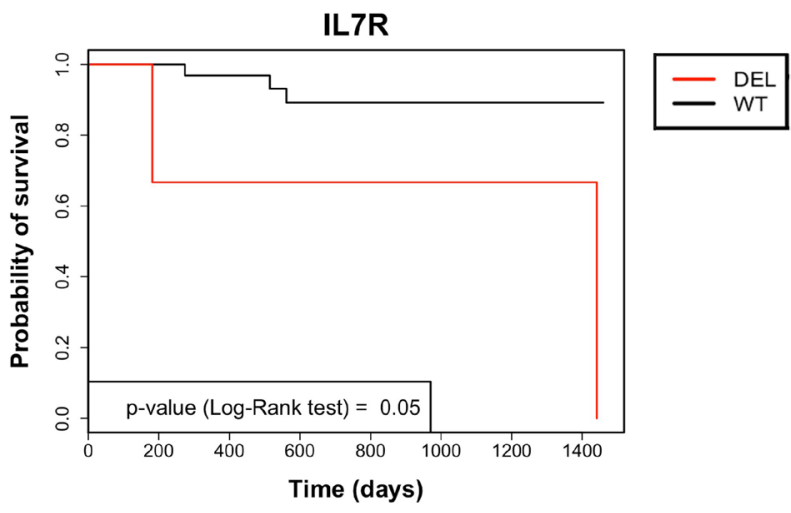

Figure 7: Kaplan-Meier analysis of 4-year survival in colon cancer patients. (A) Kaplan-Meier survival curve of OS in in colon cancer patients that were stratified for being positive or negative for CNAs in TSC1. (B) Kaplan-Meier survival curve of OS in in colon cancer patients that were stratified for being positive or negative for CNAs in IL7R. (C) Kaplan-Meier survival curve of OS in colon cancer patients that were stratified for being positive or negative for CNAs in ASXL1. 
Table 4: Genes with CNAs showing significant association with tumors arising in specific colon sites by $\chi 2$ test

\begin{tabular}{|c|c|c|c|c|c|c|c|c|}
\hline \multirow[b]{2}{*}{ GENE SYMBOL } & & \multirow[b]{2}{*}{$p$-value } & \multicolumn{6}{|c|}{ Anatomic Site } \\
\hline & & & $\begin{array}{l}\text { Ascending } \\
\text { colon } \\
(n=7)\end{array}$ & $\begin{array}{l}\text { Cecum } \\
(n=6)\end{array}$ & $\begin{array}{l}\text { Descending } \\
\text { colon } \\
(n=7)\end{array}$ & $\begin{array}{l}\text { Hepatic Flexure } \\
(n=8)\end{array}$ & $\begin{array}{l}\text { Splenic Flexure } \\
(n=5)\end{array}$ & $\begin{array}{l}\text { Transverse } \\
\text { colon }(n=4)\end{array}$ \\
\hline \multirow{11}{*}{$\begin{array}{l}\text { Genes } \\
\text { with CN LOSS }\end{array}$} & MBD1 & 0.0005 & $\begin{array}{l}\mathrm{Obs}^{*}=0 \\
\operatorname{Exp}^{* *}=0.75(10.7 \%)\end{array}$ & $\begin{array}{l}\text { Obs }=0 \\
\text { Exp }=0.64(10.7 \%)\end{array}$ & $\begin{array}{l}\text { Obs }=6(85.7 \%) \\
\operatorname{Exp}=0.75(10.7 \%)\end{array}$ & $\begin{array}{l}\text { Obs }=1(12.5 \%) \\
\text { Exp }=0.86(10.7 \%)\end{array}$ & $\begin{array}{l}\text { Obs }=3(60 \%) \\
\text { Exp }=0.54(10.7 \%)\end{array}$ & $\begin{array}{l}\text { Obs }=0 \\
\operatorname{Exp}=0.43(10.7 \%)\end{array}$ \\
\hline & PDGFB & 0.0008 & $\begin{array}{l}\text { Obs }=0 \\
\operatorname{Exp}=0.56(8 \%)\end{array}$ & $\begin{array}{l}\text { Obs }=0 \\
\operatorname{Exp}=0.48(8 \%)\end{array}$ & $\begin{array}{l}\text { Obs }=0 \\
\text { Exp }=0.56(8 \%)\end{array}$ & $\begin{array}{l}\text { Obs }=0 \\
\operatorname{Exp}=0.64(8 \%)\end{array}$ & $\begin{array}{l}\text { Obs }=3(60 \%) \\
\text { Exp }=0.4(8 \%)\end{array}$ & $\begin{array}{l}\text { Obs }=0 \\
\text { Exp }=0.32(8 \%)\end{array}$ \\
\hline & DCC & 0.002 & $\begin{array}{l}\text { Obs }=1(14.28 \%) \\
\operatorname{Exp}=2.45(35 \%)\end{array}$ & $\begin{array}{l}\text { Obs }=1(16.66 \%) \\
\text { Exp }=2.1(35 \%)\end{array}$ & $\begin{array}{l}\text { Obs }=6(85.71 \%) \\
\text { Exp }=2.45(35 \%)\end{array}$ & $\begin{array}{l}\text { Obs }=1(12.5 \%) \\
\text { Exp }=2.81(35 \%)\end{array}$ & $\begin{array}{l}\text { Obs }=4(80 \%) \\
\text { Exp }=1.75(35 \%)\end{array}$ & $\begin{array}{l}\mathrm{Obs}=0 \\
\operatorname{Exp}=1.4(35 \%)\end{array}$ \\
\hline & WRN & 0.007 & $\begin{array}{l}\text { Obs }=0 \\
\text { Exp }=0.94(13 \%)\end{array}$ & $\begin{array}{l}\text { Obs }=0 \\
\text { Exp }=0.81(13 \%)\end{array}$ & $\begin{array}{l}\text { Obs }=4(57.14 \%) \\
\text { Exp }=0.94(13 \%)\end{array}$ & $\begin{array}{l}\text { Obs }=0 \\
\operatorname{Exp}=1.08(13 \%)\end{array}$ & $\begin{array}{l}\text { Obs }=0 \\
\text { Exp }=0.67(13 \%)\end{array}$ & $\begin{array}{l}\text { Obs }=1(25 \%) \\
\operatorname{Exp}=0.54(13 \%)\end{array}$ \\
\hline & NOTCH2 & 0.007 & $\begin{array}{l}\text { Obs }=0 \\
\operatorname{Exp}=0.75(11 \%)\end{array}$ & $\begin{array}{l}\text { Obs }=1(16.66 \%) \\
\operatorname{Exp}=0.64(11 \%)\end{array}$ & $\begin{array}{l}\text { Obs }=0 \\
\operatorname{Exp}=0.75(11 \%)\end{array}$ & $\begin{array}{l}\mathrm{Obs}=0 \\
\operatorname{Exp}=0.86(11 \%)\end{array}$ & $\begin{array}{l}\text { Obs }=3(60 \%) \\
\text { Exp }=0.64(11 \%)\end{array}$ & $\begin{array}{l}\text { Obs }=0 \\
\operatorname{Exp}=0.43(11 \%)\end{array}$ \\
\hline & SMAD4 & 0.01 & $\begin{array}{l}\text { Obs }=0 \\
\operatorname{Exp}=0.56(8 \%)\end{array}$ & $\begin{array}{l}\text { Obs }=0 \\
\operatorname{Exp}=0.48(8 \%)\end{array}$ & $\begin{array}{l}\text { Obs }=3(42.85 \%) \\
\text { Exp }=0.56(8 \%)\end{array}$ & $\begin{array}{l}\text { Obs }=0 \\
\operatorname{Exp}=0.64(8 \%)\end{array}$ & $\begin{array}{l}\text { Obs }=0 \\
\text { Exp }=0.4(8 \%)\end{array}$ & $\begin{array}{l}\text { Obs }=0 \\
\operatorname{Exp}=0.32(8 \%)\end{array}$ \\
\hline & RNF213 & 0.03 & $\begin{array}{l}\text { Obs }=1(14.28 \%) \\
\operatorname{Exp}=1.7(24 \%)\end{array}$ & $\begin{array}{l}\text { Obs }=0 \\
\text { Exp }=1.45(24 \%)\end{array}$ & $\begin{array}{l}\mathrm{Obs}=5(71.42) \\
\operatorname{Exp}=1.7(24 \%)\end{array}$ & $\begin{array}{l}\text { Obs }=2(25 \%) \\
\text { Exp }=1.94(24 \%)\end{array}$ & $\begin{array}{l}\text { Obs }=0 \\
\operatorname{Exp}=1.21(24 \%)\end{array}$ & $\begin{array}{l}\text { Obs }=1(25 \%) \\
\operatorname{Exp}=0.97(24 \%)\end{array}$ \\
\hline & APC & 0.03 & $\begin{array}{l}\text { Obs }=0 \\
\operatorname{Exp}=0.94(13 \%)\end{array}$ & $\begin{array}{l}\mathrm{Obs}=0 \\
\operatorname{Exp}=0.81(13 \%)\end{array}$ & $\begin{array}{l}\mathrm{Obs}=3(42.85 \%) \\
\operatorname{Exp}=0.94(13 \%)\end{array}$ & $\begin{array}{l}\text { Obs }=0 \\
\operatorname{Exp}=1.08(13 \%)\end{array}$ & $\begin{array}{l}\text { Obs }=2(40 \%) \\
\operatorname{Exp}=0.67(13 \%)\end{array}$ & $\begin{array}{l}\mathrm{Obs}=0 \\
\operatorname{Exp}=0.54(13 \%)\end{array}$ \\
\hline & PIK3R1 & 0.03 & $\begin{array}{l}\mathrm{Obs}=0 \\
\operatorname{Exp}=0.94(13 \%)\end{array}$ & $\begin{array}{l}\mathrm{Obs}=0 \\
\operatorname{Exp}=0.81(13 \%)\end{array}$ & $\begin{array}{l}\mathrm{Obs}=3(42.85 \%) \\
\operatorname{Exp}=0.94(13 \%)\end{array}$ & $\begin{array}{l}\text { Obs }=0 \\
\operatorname{Exp}=1.08(13 \%)\end{array}$ & $\begin{array}{l}\mathrm{Obs}=2(40 \%) \\
\operatorname{Exp}=0.67(13 \%)\end{array}$ & $\begin{array}{l}\mathrm{Obs}=0 \\
\operatorname{Exp}=0.54(13 \%)\end{array}$ \\
\hline & RET & 0.04 & $\begin{array}{l}\mathrm{Obs}=0 \\
\operatorname{Exp}=1.13(16 \%)\end{array}$ & $\begin{array}{l}\mathrm{Obs}=0 \\
\operatorname{Exp}=0.97(16 \%)\end{array}$ & $\begin{array}{l}\mathrm{Obs}=2(28.57 \%) \\
\operatorname{Exp}=1.13(16 \%)\end{array}$ & $\begin{array}{l}\mathrm{Obs}=1(12.5 \%) \\
\operatorname{Exp}=1.29(16 \%)\end{array}$ & $\begin{array}{l}\mathrm{Obs}=3(60 \%) \\
\operatorname{Exp}=0.81(16 \%)\end{array}$ & $\begin{array}{l}\mathrm{Obs}=0 \\
\operatorname{Exp}=0.64(16 \%)\end{array}$ \\
\hline & PKHD1 & 0.04 & $\begin{array}{l}\mathrm{Obs}=0 \\
\operatorname{Exp}=1.13(16 \%)\end{array}$ & $\begin{array}{l}\mathrm{Obs}=0 \\
\operatorname{Exp}=0.97(16 \%)\end{array}$ & $\begin{array}{l}\mathrm{Obs}=2(28.57 \%) \\
\operatorname{Exp}=1.13(16 \%)\end{array}$ & $\begin{array}{l}\text { Obs }=1(12.5 \%) \\
\operatorname{Exp}=1.29(16 \%)\end{array}$ & $\begin{array}{l}\mathrm{Obs}=3(60 \%) \\
\mathrm{Exp}=0.81(16 \%)\end{array}$ & $\begin{array}{l}\mathrm{Obs}=0 \\
\operatorname{Exp}=0.64(16 \%)\end{array}$ \\
\hline \multirow{3}{*}{$\begin{array}{l}\text { Genes with CN } \\
\text { GAIN }\end{array}$} & RB1 & 0.01 & $\begin{array}{l}\text { Obs }=0 \\
\operatorname{Exp}=0.56(8 \%)\end{array}$ & $\begin{array}{l}\mathrm{Obs}=0 \\
\operatorname{Exp}=0.48(8 \%)\end{array}$ & $\begin{array}{l}\text { Obs }=3(42.85 \%) \\
\operatorname{Exp}=0.56(8 \%)\end{array}$ & $\begin{array}{l}\text { Obs }=0 \\
\operatorname{Exp}=0.64(8 \%)\end{array}$ & $\begin{array}{l}\text { Obs }=0 \\
\operatorname{Exp}=0.4(8 \%)\end{array}$ & $\begin{array}{l}\text { Obs }=0 \\
\operatorname{Exp}=0.32(8 \%)\end{array}$ \\
\hline & BCL2L1 & 0.01 & $\begin{array}{l}\text { Obs }=0 \\
\operatorname{Exp}=0.37(5 \%)\end{array}$ & $\begin{array}{l}\text { Obs }=0 \\
\operatorname{Exp}=0.32(5 \%)\end{array}$ & $\begin{array}{l}\text { Obs }=0 \\
\operatorname{Exp}=0.37(5 \%)\end{array}$ & $\begin{array}{l}\text { Obs }=0 \\
\operatorname{Exp}=0.43(5 \%)\end{array}$ & $\begin{array}{l}\text { Obs }=2(40 \%) \\
\operatorname{Exp}=0.27(5 \%)\end{array}$ & $\begin{array}{l}\mathrm{Obs}=0 \\
\operatorname{Exp}=0.21(5 \%)\end{array}$ \\
\hline & UBR5 & 0.02 & $\begin{array}{l}\mathrm{Obs}=0 \\
\operatorname{Exp}=2.45(35 \%)\end{array}$ & $\begin{array}{l}\mathrm{Obs}=0 \\
\operatorname{Exp}=2.1(5 \%)\end{array}$ & $\begin{array}{l}\mathrm{Obs}=4(57.14 \%) \\
\operatorname{Exp}=2.45(5 \%)\end{array}$ & $\begin{array}{l}\text { Obs }=3(37.5 \%) \\
\operatorname{Exp}=2.81(5 \%)\end{array}$ & $\begin{array}{l}\text { Obs }=4(80 \%) \\
\operatorname{Exp}=1.75(5 \%)\end{array}$ & $\begin{array}{l}\text { Obs }=2(50 \%) \\
\operatorname{Exp}=1.4(5 \%)\end{array}$ \\
\hline
\end{tabular}

*Obs: Observed CC patients showing CNAs.

${ }^{* *}$ Exp: Expected CC patients showing CNAs.

provides full exon coverage of the 409 most important cancer-associated genes. The main results reported in this manuscript were: i) the successful detection of somatic CNAs in 230 genes from NGS amplicon-based libraries in CC samples (143 genes with CN losses and 87 genes with $\mathrm{CN}$ gains), ii) the identification of clinically relevant CNAs in genes such as ASXL1, TSC1 and IL7R, iii) the identification of CNAs in 4 genes in tumors originating from all colon segments ("common genes") and iv) the detection of CNAs in 14 genes associated preferentially to a specific colon site ("site-associated genes").

The main characteristic of the approach described by Grasso et al., and applied here, was to use read counts/ amplicon to identify CNAs from NGS data. Prediction of gene amplification/deletion is possible if sufficient number of amplicons is analyzed [54]. Overall, we have found a total of 785 significant CNAs in 243 different genes, of which 328 were $\mathrm{CN}$ gains and 457 were $\mathrm{CN}$ losses. The results obtained in silico with the Amplicon CNA Algorithm were validated by quantitative Q-PCR and immunostaining. Further control of our results was performed by combining information from COADTCGA database and sequencing data presented in this manuscript. From this analysis it appears that almost
$30 \%$ of the 230 genes with significant CNAs in CC showed a statistically significant correlation with mRNA expression, at difference with a similar analysis using the COAD-TCGA dataset, in which $20 \%$ of genes (3542 out of 17630) presented a positive correlation between CNAs and mRNA expression $\left(R^{2}>0.2 ; p \leq 0.01\right)$.

Previous studies have reported that in colon cancer chr20 was most frequently subjected to $\mathrm{CN}$ gains and chr18 was most frequently subjected to $\mathrm{CN}$ losses [55]. In agreement with these previous reports, the genes most frequently subjected to $\mathrm{CN}$ gains observed in this study were located on chromosome 20 including ASXL1, PLCG1, TOP1 and PTPRT whereas the genes most frequently subjected to $\mathrm{CN}$ losses were located on chromosome 18 and include MBD1, DCC and CDH2. Most of the genes that presented CNAs identified in this manuscript, such as TOP1, ASXL1, PTPRD, DCC, NLRP1 and $\mathrm{CDH} 2$ have already been directly associated with the development of CC. In particular, gene amplification and/ or overexpression of TOP1 has been detected in metastatic colon cancer whereas loss of ASXL1 occurs in CC with microsatellite instability [56]. Loss of PTPRD expression was observed in highly invasive cancers and correlated with patient survival [57]. 
Some of the genes that presented the highest values of CNAs have already been associated with CC. In particular, gene amplification and/or overexpression of CCND1 have been associated with poor prognosis and reduced overall survival in $\mathrm{CC}$ patients whereas BCL2L1 has been shown to play a role in the adenomato-carcinoma progression $[58,59]$. Less clear is the role of MAF having been described either as an oncogene or as a tumor suppressor, depending on the cell context [60].

On the other hand, at least 10 , among the 230 genes showing CNAs, were not known to be associated to CC. Among these TGM7, NKX2-1, RHOH, RNF213, ERG, and $\mathrm{CRBN}$ presented significant $\mathrm{CN}$ losses and thus were potential tumor suppressor genes whereas DST, KLF6, FANCA, CSMD3 presented significant $\mathrm{CN}$ gains and can be considered potential oncogenes.

Notably, we observed that $\mathrm{CN}$ gain of ASXL1 was associated with an improvement in OS, whereas CN loss of TSC1 and IL7R predicted significantly reduced OS.

An important aim of this study was to determine whether tumors arising in different colon segments presented specific molecular alterations. Overall we have identified 4 "common genes" subjected to CNAs in tumors originating from all colon segments and 14 "site-associated genes" whose alterations are associated to tumors arising in specific colon segments. Among the 4 "common genes" we found CN gains in ASXL1 and PLGC1, which suggest that they act as oncogenes in CC. However previous studies showing the involvement of ASXL1 and PLGC1 in the development of CC were inconsistent. In fact both ASXL1 and PLGC1 have been shown to act either as tumor suppressor genes or oncogenes [56, 61]. Among the "common genes" presenting $\mathrm{CN}$ losses identified in this study is NLRP1, a protein whose function is apparently involved in gastrointestinal inflammation and tumorigenesis [62].

Among the 14 "site-associated genes" that showed highly significant association with a specific colon segment, PDGFB, SMAD4, RB1, BCL2L1 showed anatomical position dependency for only one colon segment, WRN, NOTCH2, APC and PIK3R1 showed anatomical position dependency for two colon segments whereas the remaining genes PKHD1, RET, MDB1 RNF213, UBR5 and DCC were associated to 3 or more segments. Moreover, a further support to the significance of the association reported in this study, was the finding that 7 out of the 14 "site-associated genes" reported here showed a significant position dependency also in the cohort of tumors present within the COAD-TCGA database. In particular, CNAs in MBD1, SMAD4, PIK3R1, DCC, WRN, RB1 were significantly associated with tumors originating in descending colon whereas CNAs in NOTCH2 was associated with tumors originating in splenic flexure.

It is also of note that loss of "site-associated" genes such as WRN, NOTCH2, MBD1 and PI3KR1 had already been associated to development of human cancer. In particular, WRN has been reported to be frequently deleted in $\mathrm{CC}$, and its deficiency apparently predisposes to various types of cancer [22]. In the present study WNR was found to be lost preferentially in descending colon tumors. Similarly, in agreement with the existing literature [63], we found that $\mathrm{NOTCH} 2$ was deleted in $\mathrm{CC}$ (preferentially in splenic flexure tumors), which suggested a role as tumor suppressor in this subset of CC. On the other hand, we have found that MBD1 loss is a frequent event in colon carcinogenesis, being associated with descending colon tumors in different studies. This observation is in agreement with previous studies reporting frequent deletion of 18q21 (where MBD1 maps) in CC [64]. Notably, the results described in the present study show a significant association between MBD1 loss and late stage of disease. Finally, loss of PIK3R1 was preferentially observed in descending colon tumors. PIK3R1 represents the $\mathrm{p} 85$ regulatory subunit of heterodimeric enzymes, the PI3Ks, which also include a p110 catalytic subunit [65]. PI3Ks are downstream effectors of tyrosine kinase and G-protein-coupled receptors, which coordinate multiple cell functions including proliferation, migration and survival $[66,67]$. PIK3R1 plays an important role in restraining cell migration. Loss of PIK3R1 was observed in patients with stage III disease (5/12 patients) but in none of the patients with stage I or II disease $(0 / 20)$, suggesting that its down-regulation promotes aberrant activation of PI3K signalling in colon cancer cells, which would lead to invasion of adjacent tissues and/or regional dissemination.

In conclusion, in this study we report the successful detection of somatic CNAs in 230 genes using NGS data relative to $37 \mathrm{CC}$ samples. Expectedly, most genes showing CNAs had already been reported to be associated with $\mathrm{CC}$ [22] whereas at least 10 among the 230 altered genes had not apparently been associated to CC yet. Notably, the analysis reported in this study indicated that $\mathrm{CN}$ changes in at least 3 genes (ASXL1, TSC1 and IL7R) were clinically relevant, being their alteration associated with survival. Finally, the analysis of the distribution of genes with CNAs relative to the site of origin of cancer led to the identification of 4 "common genes" that were subjected to CNAs in tumors arising in all 6 colon segments and 14 "site-associated genes" whose CNAs occurs preferentially in tumors originating only in certain colon segments.

\section{MATERIALS AND METHODS}

\section{Ethics statement}

Accrual of patients was conducted according to Institutional Review Board of the AOU Mater Domini/ University Magna Graecia (Catanzaro, Italy). The study was approved by the Institutional Review Board of the AOU Mater Domini/University Magna Graecia in the meeting of May 21st, 2014. 


\section{Tumor samples}

Tumor samples, matched normal mucosa and peripheral blood lymphocytes (PBL) were obtained from patients referring to General Surgery unit of the AOU Mater Domini/University Magna Graecia (Catanzaro, Italy), who underwent surgical resection for colon cancer since January 2013. Biopsies were immediately snap frozen and stored at $-80^{\circ}$ C. Hematoxylin and eosinstained tissue sections were reviewed by an expert pathologist to confirm diagnosis.

\section{Patients' demographics}

General demographic information, histo-patological and clinical parameters, surgical treatment and follow-up data were collected prospectively and are also reported in Oliveira et al. (submitted). However, for sake of clarity we summarize below the clinical characteristics of the patients included in the study.

Among the 37 patients, 13 were women and 24 were males. Mean age of patients was 68.35 years old (range 47-84). Stage was known for 36 of the 37 patients: 7 patients had stage I disease, 13 patients had stage II disease, 12 patients had stage III disease and 4 patients had stage IV disease. Grade was known for 35 out of 37 patients: 1 patient had tumor that was graded G1, 25 patients had tumors that were graded G2 and 9 patients had tumors that were graded G3. Of the patients included in the present study, four presented distant metastasis. None of the patients received chemotherapy or radiation therapy prior to surgery.

\section{Bioinformatic analysis for $\mathrm{CNV}$ detection}

DNA extraction, library preparation using the Ion AmpliSeq ${ }^{\mathrm{TM}}$ Comprehensive Cancer Panel on the Ion Torrent platform (Thermofisher, MA, USA), sequencing and NGS primary analysis were carried out as described (Oliveira et al., submitted).

To identify CNAs in NGS amplicon-based dataset we replaced average coverage of exon pull-down regions with read counts per amplicon. All reads were aligned to the human reference genome (hg19). For each sample, normalization was performed by dividing the number of reads of each amplicon by the total number of reads. Subsequently, the normalized reads obtained as described from tumor samples were divided by the normalized reads from pool made of blood samples from 13 patients, set as reference. The resulting Log2 values (raw copy number ratios) were corrected for the GC content in each amplicon and the Poisson model was applied using the CNA amplicon algorithm described in Grasso et al. [52] to identify CNAs. Genes were defined significant when the $q$-value was $\leq 0.05$ after the Benjamini-Hochberg correction [68]. CN gains were defined as genes showing $\log 2 \mathrm{CN}$ ratio $\geq 0.1$ and $\mathrm{CN}$ losses were defined as genes showing $\log 2 \mathrm{CN}$ ratio $\leq-0.1$.

\section{Association and survival studies}

The association between genes showing CNAs and the clinical-pathological parameters was evaluated by Fisher's exact test and $\chi^{2}$ test. Overall survival (OS) was calculated from the day of surgery to death or end of follow-up. Kaplan-Meier curves were used for analysis of OS.

Univariate and multivariate survival analyses with calculation of hazard ratios (HR) were performed using Cox's proportional-hazards model. $\mathrm{R}$ software was used for statistical analysis and a $p$-value $\leq 0.05$ was considered significant.

Regarding the correlation of CNA with mRNA expression, a gene-level table of copy number values and gene expression data were downloaded from the COAD-TCGA dataset. Using as input CNA and miRNA expression, we describe the relationship between these variables by linear regression analysis setting as significant Pearson correlation value $>0.45\left(R^{2}>0.2, p\right.$-value $\left.\leq 0.01\right)$

\section{Quantitative real-time (Q-PCR)}

To validate bioinformatic analysis of $\mathrm{CN}$ alterations we performed real-time PCR in selected genes. We used GAPDH to normalize the data and PBLs as reference samples. Reactions were performed using SYBR Green I PCR Master Mix (Thermofisher), which includes the internal reference (ROX). Each qPCR reaction comprised $10 \mu \mathrm{l} 2 \times$ SYBR Green PCR Master Mix, forward and reverse primers at final concentration of $500 \mathrm{nM}$. QPCR reactions were performed using the Quantstudio $12 \mathrm{~K}$ Flex (Thermofisher). The reaction profile was: initial step, $50^{\circ} \mathrm{C}$ for $2 \mathrm{~min}$, denaturation, $95^{\circ} \mathrm{C}$ for $10 \mathrm{~min}$, then 40 cycles of denaturing at $95^{\circ} \mathrm{C}$ for $15 \mathrm{sec}$ and combined annealing and extension at $60^{\circ} \mathrm{C}$ for $60 \mathrm{sec}$. Each qPCR experiment contained triplicates of the no-template-controls and test samples for all of the primers tested. Three independent experiments were conducted for each analysis. Statistical analysis was performed with one-way ANOVA and Dunnett's multiple comparisons test using Graphpad software. ${ }^{*} p<0.05,{ }^{* *} p<$ $0.01,{ }^{* * *} p<0.001$ and $^{* * * *} p<0.0001$.

\section{Immunoistochemistry}

Immunostaining was performed with standard protocols using Bond ${ }^{\mathrm{TM}}$ Polymer Refine Detection Kit (Leica Biosystem, Buffalo Grove, IL) according to the manufacturer's instructions, on formalin-fixed, paraffinembedded tissues. Sections $(5 \mu \mathrm{m})$ were mounted on slides and stained with hematoxylin and eosin to be evaluated by light microscopy. The antibody used in immunostaining for CCND1 (\#3642, DAKO, Carpinteria, CA, USA). 


\section{Author contributions}

Duarte Mendes Oliveira: Participated in the conception, design and execution of the study; performed the NGS sequencing runs and validation experiments; writing and editing of the manuscript; Gianluca Santamaria: Participated in the analysis and interpretation of data; drafting and editing of the manuscript; Carmelo Laudanna: Participated in bioinformatic analysis and intrepertation of NGS data; Pietro Zoppoli: Participated in bioinformatic analysis and intrepertation of NGS data; Simona Migliozzi: Participated in bioinformatic analysis and intrepertation of NGS data; Michael Quist: Provided bionformatic tools and revised the draft of the manuscript; Catie Grasso: Provided bionformatic tools and revised the draft of the manuscript; Chiara Mignogna: Revision of pathologic slides; Laura Elia: Participated in patient recruitment and collected clinical information; Maria Concetta Faniello: Participated in data collection; Cinzia Marinaro: Participated in data collection; Rosario Sacco: Performed the operations; Donatella Malanga: Participated in data collection, execution of the study and the analysis and interpretation of data; assisted extensively in writing the manuscript and critical revision; Francesco Corcione: Assisted in writing the manuscript and critical revision; Antonia Rizzuto: Performed the operations; participated in the design of the study; collected clinical data of patients; helped in data interpretation; Giuseppe Viglietto: Supervised development of work, helped in data interpretation, assisted extensively in writing the manuscript and critical revision.

\section{CONFLICTS OF INTEREST}

The authors declare no conflicts of interest.

\section{GRANT SUPPORT}

This work was supported by MIUR (PON01_02782; PON03_0475) and by Centro Interdipartimentale di Servizi of the University Magna Graecia of Catanzaro.

\section{REFERENCES}

1. Futreal PA, Coin L, Marshall M, Down T, Hubbard T, Wooster R, Rahman N, Stratton MR. A census of human cancer genes. Nat Rev Cancer. 2004; 4:177-83.

2. Stuart D, Sellers WR. Linking somatic genetic alterations in cancer to therapeutics. Curr Opin Cell Biol. 2009; 21:304-10.

3. Redon R, Ishikawa S, Fitch KR, Feuk L, Perry GH, Andrews TD, Fiegler H, Shapero MH, Carson AR, Chen W, Cho EK, Dallaire S, Freeman JL, et al. Global variation in copy number in the human genome. Nature. 2006; 444:444-54.
4. Stratton MR, Campbell PJ, Futreal PA. The cancer genome. Nature. 2009; 458:719-24.

5. NCI and NCBI's SKY/M-FISH and CGH Database. https:// www.ncbi.nlm.nih.gov/dbvar/studies/nstd136/\#samplesetsTab. 2001.

6. Baudis M. Genomic imbalances in 5918 malignant epithelial tumors: an explorative meta-analysis of chromosomal CGH data. BMC Cancer. 2007; 7:226.

7. Beroukhim R, Mermel CH, Porter D, Wei G, Raychaudhuri S, Donovan J, Barretina J, Boehm JS, Dobson J, Urashima M, Mc Henry KT, Pinchback RM, Ligon AH, et al. The landscape of somatic copy-number alteration across human cancers. Nature. 2010; 463:899-905.

8. Kim TM, Xi R, Luquette LJ, Park RW, Johnson MD, Park PJ. Functional genomic analysis of chromosomal aberrations in a compendium of 8000 cancer genomes. Genome Res. 2013; 23:217-27.

9. Mitelman FJ, Mertens BF. Mitelman Database of Chromosome Aberrations in Cancer. https://ulib.iupui.edu/ databases/mitelman-database-chromosome-aberrations-andgene-fusions-cancer.

10. Stephens PJ, McBride DJ, Lin ML, Varela I, Pleasance ED, Simpson JT, Stebbings LA, Leroy C, Edkins S, Mudie LJ, Greenman CD, Jia M, Latimer C, et al. Complex landscapes of somatic rearrangement in human breast cancer genomes. Nature. 2009; 462:1005-10.

11. Weir BA, Woo MS, Getz G, Perner S, Ding L, Beroukhim R, Lin WM, Province MA, Kraja A, Johnson LA, Shah K, Sato $\mathrm{M}$, Thomas RK, et al. Characterizing the cancer genome in lung adenocarcinoma. Nature. 2007; 450:893-98.

12. Hammerman PS, Lawrence MS, Voet D, Jing R, Cibulskis K, Sivachenko A, Stojanov P, McKenna A, Lander ES, Gabriel S, Getz G, Sougnez C, Imielinski M, et al, and Cancer Genome Atlas Research Network. Comprehensive genomic characterization of squamous cell lung cancers. Nature. 2012; 489:519-25.

13. Xue W, Kitzing T, Roessler S, Zuber J, Krasnitz A, Schultz N, Revill K, Weissmueller S, Rappaport AR, Simon J, Zhang J, Luo W, Hicks J, et al. A cluster of cooperating tumor-suppressor gene candidates in chromosomal deletions. Proc Natl Acad Sci U S A. 2012; 109:8212-17.

14. Nik-Zainal S, Van Loo P, Wedge DC, Alexandrov LB, Greenman CD, Lau KW, Raine K, Jones D, Marshall J, Ramakrishna M, Shlien A, Cooke SL, Hinton J, et al, and Breast Cancer Working Group of the International Cancer Genome Consortium. The life history of 21 breast cancers. Cell. 2012; 149:994-1007.

15. Harada T, Chelala C, Bhakta V, Chaplin T, Caulee K, Baril P, Young BD, Lemoine NR. Genome-wide DNA copy number analysis in pancreatic cancer using high-density single nucleotide polymorphism arrays. Oncogene. 2008; 27:1951-60.

16. Xie T, D' Ario G, Lamb JR, Martin E, Wang K, Tejpar $\mathrm{S}$, Delorenzi M, Bosman FT, Roth AD, Yan P, Bougel S, 
Di Narzo AF, Popovici V, et al. A comprehensive characterization of genome-wide copy number aberrations in colorectal cancer reveals novel oncogenes and patterns of alterations. PLoS One. 2012; 7:e42001.

17. Tsao MS, Sakurada A, Cutz JC, Zhu CQ, Kamel-Reid S, Squire J, Lorimer I, Zhang T, Liu N, Daneshmand M, Marrano P, da Cunha Santos G, Lagarde A, et al. Erlotinib in lung cancer - molecular and clinical predictors of outcome. N Engl J Med. 2005; 353:133-44.

18. Cheang MC, Chia SK, Voduc D, Gao D, Leung S, Snider J, Watson M, Davies S, Bernard PS, Parker JS, Perou CM, Ellis MJ, Nielsen TO. Ki67 index, HER2 status, and prognosis of patients with luminal B breast cancer. J Natl Cancer Inst. 2009; 101:736-50.

19. Kim ES, Hirsh V, Mok T, Socinski MA, Gervais R, Wu YL, Li LY, Watkins CL, Sellers MV, Lowe ES, Sun Y, Liao ML, Osterlind K, et al. Gefitinib versus docetaxel in previously treated non-small-cell lung cancer (INTEREST): a randomised phase III trial. Lancet. 2008; 372:1809-18.

20. Sheffer M, Bacolod MD, Zuk O, Giardina SF, Pincas H, Barany F, Paty PB, Gerald WL, Notterman DA, Domany E. Association of survival and disease progression with chromosomal instability: a genomic exploration of colorectal cancer. Proc Natl Acad Sci U S A. 2009; 106:7131-36.

21. Brosens RP, Belt EJ, Haan JC, Buffart TE, Carvalho B, Grabsch H, Quirke P, Cuesta MA, Engel AF, Ylstra B, Meijer GA. Deletion of chromosome 4q predicts outcome in stage II colon cancer patients. Anal Cell Pathol (Amst). 2010; 33:95-104.

22. Wang H, Liang L, Fang JY, Xu J. Somatic gene copy number alterations in colorectal cancer: new quest for cancer drivers and biomarkers. Oncogene. 2016; 35:2011-19.

23. Haan JC, Labots M, Rausch C, Koopman M, Tol J, Mekenkamp LJ, van de Wiel MA, Israeli D, van Essen HF, van Grieken NC, Voorham QJ, Bosch LJ, Qu X, et al. Genomic landscape of metastatic colorectal cancer. Nat Commun. 2014; 5:5457.

24. AIRTUM GdlA. I numeri del cancro in Italia: Intermedia Editore, Breascia. 2014.

25. Fearon ER. Molecular genetics of colorectal cancer. Annu Rev Pathol. 2011; 6:479-507.

26. Sayagués JM, Fontanillo C, Abad MM, González-González M, Sarasquete ME, Chillon MC, Garcia E, Bengoechea O, Fonseca E, Gonzalez-Diaz M, De las Rivas J, MuñozBellvis L, Orfao A. Mapping of genetic abnormalities of primary tumours from metastatic CRC by high-resolution SNP arrays. PLoS One. 2010; 5:e13752.

27. Ashktorab H, Schäffer AA, Daremipouran M, Smoot DT, Lee E, Brim H. Distinct genetic alterations in colorectal cancer. PLoS One. 2010; 5:e8879.

28. Kurashina K, Yamashita Y, Ueno T, Koinuma K, Ohashi J, Horie H, Miyakura Y, Hamada T, Haruta H, Hatanaka H, Soda M, Choi YL, Takada S, et al. Chromosome copy number analysis in screening for prognosis-related genomic regions in colorectal carcinoma. Cancer Sci. 2008; 99:1835-40.

29. Platzer P, Upender MB, Wilson K, Willis J, Lutterbaugh J, Nosrati A, Willson JK, Mack D, Ried T, Markowitz S. Silence of chromosomal amplifications in colon cancer. Cancer Res. 2002; 62:1134-38.

30. Ried T, Knutzen R, Steinbeck R, Blegen H, Schröck E, Heselmeyer K, du Manoir S, Auer G. Comparative genomic hybridization reveals a specific pattern of chromosomal gains and losses during the genesis of colorectal tumors. Genes Chromosomes Cancer. 1996; 15:234-45.

31. Douglas EJ, Fiegler H, Rowan A, Halford S, Bicknell DC, Bodmer W, Tomlinson IP, Carter NP. Array comparative genomic hybridization analysis of colorectal cancer cell lines and primary carcinomas. Cancer Res. 2004; 64:4817-25.

32. Nakao K, Mehta KR, Fridlyand J, Moore DH, Jain AN, Lafuente A, Wiencke JW, Terdiman JP, Waldman FM. High-resolution analysis of DNA copy number alterations in colorectal cancer by array-based comparative genomic hybridization. Carcinogenesis. 2004; 25:1345-57.

33. Camps J, Nguyen QT, Padilla-Nash HM, Knutsen T, McNeil NE, Wangsa D, Hummon AB, Grade M, Ried T, Difilippantonio MJ. Integrative genomics reveals mechanisms of copy number alterations responsible for transcriptional deregulation in colorectal cancer. Genes Chromosomes Cancer. 2009; 48:1002-17.

34. Ji H, Kumm J, Zhang M, Farnam K, Salari K, Faham M, Ford JM, Davis RW. Molecular inversion probe analysis of gene copy alterations reveals distinct categories of colorectal carcinoma. Cancer Res. 2006; 66:7910-19.

35. Bartos JD, Gaile DP, McQuaid DE, Conroy JM, Darbary H, Nowak NJ, Block A, Petrelli NJ, Mittelman A, Stoler DL, Anderson GR. aCGH local copy number aberrations associated with overall copy number genomic instability in colorectal cancer: coordinate involvement of the regions including BCR and ABL. Mutat Res. 2007; 615:1-11.

36. Brosens RP, Haan JC, Carvalho B, Rustenburg F, Grabsch H, Quirke P, Engel AF, Cuesta MA, Maughan N, Flens M, Meijer GA, Ylstra B. Candidate driver genes in focal chromosomal aberrations of stage II colon cancer. J Pathol. 2010; 221:411-24.

37. Martin ES, Tonon G, Sinha R, Xiao Y, Feng B, Kimmelman AC, Protopopov A, Ivanova E, Brennan C, Montgomery K, Kucherlapati R, Bailey G, Redston M, et al. Common and distinct genomic events in sporadic colorectal cancer and diverse cancer types. Cancer Res. 2007; 67:10736-43.

38. Postma C, Koopman M, Buffart TE, Eijk PP, Carvalho B, Peters GJ, Ylstra B, van Krieken JH, Punt CJ, Meijer GA. DNA copy number profiles of primary tumors as predictors of response to chemotherapy in advanced colorectal cancer. Annals of Oncology. 2009; 20:1048-1056. 
39. Diep CB, Kleivi K, Ribeiro FR, Teixeira MR, Lindgjaerde OC, Lothe RA. The order of genetic events associated with colorectal cancer progression inferred from meta-analysis of copy number changes. Genes Chromosomes Cancer. 2006; 45:31-41.

40. Venkatachalam R, Ligtenberg MJ, Hoogerbrugge N, Geurts van Kessel A, Kuiper RP. Predisposition to colorectal cancer: exploiting copy number variation to identify novel predisposing genes and mechanisms. Cytogenet Genome Res. 2008; 123:188-94.

41. Nakao M, Kawauchi S, Furuya T, Uchiyama T, Adachi J, Okada T, Ikemoto K, Oga A, Sasaki K. Identification of DNA copy number aberrations associated with metastases of colorectal cancer using array $\mathrm{CGH}$ profiles. Cancer Genet Cytogenet. 2009; 188:70-76.

42. Poulogiannis G, Ichimura K, Hamoudi RA, Luo F, Leung SY, Yuen ST, Harrison DJ, Wyllie AH, Arends MJ. Prognostic relevance of DNA copy number changes in colorectal cancer. J Pathol. 2010; 220:338-47.

43. Pillaire MJ, Selves J, Gordien K, Gourraud PA, Gentil C, Danjoux M, Do C, Negre V, Bieth A, Guimbaud R, Trouche $\mathrm{D}$, Pasero P, Méchali M, et al. A 'DNA replication' signature of progression and negative outcome in colorectal cancer. Oncogene. 2010; 29:876-87.

44. Carvalho B, Postma C, Mongera S, Hopmans E, Diskin S, van de Wiel MA, van Criekinge W, Thas O, Matthäi A, Cuesta MA, Terhaar Sive Droste JS, Craanen M, Schröck E, et al. Multiple putative oncogenes at the chromosome 20q amplicon contribute to colorectal adenoma to carcinoma progression. Gut. 2009; 58:79-89.

45. Lin $\mathrm{CH}$, Lin JK, Chang SC, Chang YH, Chang HM, Liu JH, Li LH, Chen YT, Tsai SF, Chen WS. Molecular profile and copy number analysis of sporadic colorectal cancer in Taiwan. J Biomed Sci. 2011; 18:36.

46. Eldai H, Periyasamy S, Al Qarni S, Al Rodayyan M, Muhammed Mustafa S, Deeb A, Al Sheikh E, Afzal M, Johani M, Yousef Z, Aziz MA. Novel genes associated with colorectal cancer are revealed by high resolution cytogenetic analysis in a patient specific manner. PLoS One. 2013; 8:e76251.

47. Pinkel D, Segraves R, Sudar D, Clark S, Poole I, Kowbel D, Collins C, Kuo WL, Chen C, Zhai Y, Dairkee SH, Ljung BM, Gray JW, Albertson DG. High resolution analysis of DNA copy number variation using comparative genomic hybridization to microarrays. Nat Genet. 1998; 20:207-11.

48. Sharp AJ, Locke DP, McGrath SD, Cheng Z, Bailey JA, Vallente RU, Pertz LM, Clark RA, Schwartz S, Segraves R, Oseroff VV, Albertson DG, Pinkel D, Eichler EE. Segmental duplications and copy-number variation in the human genome. Am J Hum Genet. 2005; 77:78-88.

49. McCarroll SA, Kuruvilla FG, Korn JM, Cawley S, Nemesh J, Wysoker A, Shapero MH, de Bakker PI, Maller JB, Kirby A, Elliott AL, Parkin M, Hubbell E, et al. Integrated detection and population-genetic analysis of SNPs and copy number variation. Nat Genet. 2008; 40:1166-74.
50. Liu B, Morrison CD, Johnson CS, Trump DL, Qin M, Conroy JC, Wang J, Liu S. Computational methods for detecting copy number variations in cancer genome using next generation sequencing: principles and challenges. Oncotarget. 2013; 4:1868-81. https://doi.org/10.18632/ oncotarget.1537.

51. Lonigro RJ, Grasso CS, Robinson DR, Jing X, Wu YM, Cao X, Quist MJ, Tomlins SA, Pienta KJ, Chinnaiyan AM. Detection of somatic copy number alterations in cancer using targeted exome capture sequencing. Neoplasia. 2011; 13:1019-25.

52. Grasso C, Butler T, Rhodes K, Quist M, Neff TL, Moore S, Tomlins SA, Reinig E, Beadling C, Andersen M, Corless CL. Assessing copy number alterations in targeted, amplicon-based next-generation sequencing data. J Mol Diagn. 2015; 17:53-63.

53. R Development Core Team. R: A language and environment for statistical computing. Vienna: $\mathrm{R}$ Foundation for Statistical Computing; 2010.

54. Budczies J, Bockmayr M, Denkert C, Klauschen F, Gröschel S, Darb-Esfahani S, Pfarr N, Leichsenring J, Onozato ML, Lennerz JK, Dietel M, Fröhling S, Schirmacher P, et al. Pan-cancer analysis of copy number changes in programmed death-ligand 1 (PD-L1, CD274) - associations with gene expression, mutational load, and survival. Genes Chromosomes Cancer. 2016; 55:626-39.

55. Jasmine F, Rahaman R, Dodsworth C, Roy S, Paul R, Raza M, Paul-Brutus R, Kamal M, Ahsan H, Kibriya MG. A genome-wide study of cytogenetic changes in colorectal cancer using SNP microarrays: opportunities for future personalized treatment. PLoS One. 2012; 7:e31968.

56. Katoh M. Functional and cancer genomics of ASXL family members. Br J Cancer. 2013; 109:299-306.

57. Funato K, Yamazumi Y, Oda T, Akiyama T. Tyrosine phosphatase PTPRD suppresses colon cancer cell migration in coordination with CD44. Exp Ther Med. 2011; 2:457-63.

58. Rømer MU, Jensen NF, Nielsen SL, Müller S, Nielsen $\mathrm{KV}$, Nielsen HJ, Brünner N. TOP1 gene copy numbers in colorectal cancer samples and cell lines and their association to in vitro drug sensitivity. Scand J Gastroenterol. 2012; 47:68-79.

59. Bahnassy AA, Zekri AR, El-Houssini S, El-Shehaby AM, Mahmoud MR, Abdallah S, El-Serafi M. Cyclin A and cyclin D1 as significant prognostic markers in colorectal cancer patients. BMC Gastroenterol. 2004; 4:22.

60. Hurt EM, Wiestner A, Rosenwald A, Shaffer AL, Campo E, Grogan T, Bergsagel PL, Kuehl WM, Staudt LM. Overexpression of c-maf is a frequent oncogenic event in multiple myeloma that promotes proliferation and pathological interactions with bone marrow stroma. Cancer Cell. 2004; 5:191-99.

61. Behjati S, Tarpey PS, Sheldon H, Martincorena I, Van Loo P, Gundem G, Wedge DC, Ramakrishna M, Cooke SL, Pillay N, Vollan HK, Papaemmanuil E, Koss H, et al. 
Recurrent PTPRB and PLCG1 mutations in angiosarcoma. Nat Genet. 2014; 46:376-79.

62. Williams TM, Leeth RA, Rothschild DE, Coutermarsh-Ott SL, McDaniel DK, Simmons AE, Heid B, Cecere TE, Allen IC. The NLRP1 inflammasome attenuates colitis and colitisassociated tumorigenesis. J Immunol. 2015; 194:3369-80.

63. Chu D, Zhang Z, Zhou Y, Wang W, Li Y, Zhang H, Dong G, Zhao Q, Ji G. Notch1 and Notch2 have opposite prognostic effects on patients with colorectal cancer. Annals of Oncology. 2011; 22:2440-2447.

64. Derks S, Bosch LJ, Niessen HE, Moerkerk PT, van den Bosch SM, Carvalho B, Mongera S, Voncken JW, Meijer GA, de Bruïne AP, Herman JG, van Engeland M. Promoter $\mathrm{CpG}$ island hypermethylation- and $\mathrm{H} 3 \mathrm{~K} 9 \mathrm{me} 3$ and H3K27me3-mediated epigenetic silencing targets the deleted in colon cancer (DCC) gene in colorectal carcinogenesis without affecting neighboring genes on chromosomal region 18q21. Carcinogenesis. 2009; 30:1041-48.
65. Yu J, Zhang Y, McIlroy J, Rordorf-Nikolic T, Orr GA, Backer JM. Regulation of the p85/p110 phosphatidylinositol 3'-kinase: stabilization and inhibition of the p110alpha catalytic subunit by the p 85 regulatory subunit. Mol Cell Biol. 1998; 18:1379-87.

66. Lin Y, Yang Z, Xu A, Dong P, Huang Y, Liu H, Li F, Wang H, Xu Q, Wang Y, Sun D, Zou Y, Zou X, et al. PIK3R1 negatively regulates the epithelial-mesenchymal transition and stem-like phenotype of renal cancer cells through the AKT/GSK3ß/CTNNB1 signaling pathway. Sci Rep. 2015; 5:8997.

67. Wen F, He S, Sun C, Li T, Wu S. PIK3CA and PIK3CB expression and relationship with multidrug resistance in colorectal carcinoma. Int J Clin Exp Pathol. 2014; 7:8295-303.

68. Benjamini Y, Hochberg Y. Controlling the False Discovery Rate: A Practical and Powerful Approach to Multiple Testing. J R Stat Soc Ser A Stat Soc. 1995; 57:289-300. 